\title{
Localization of Sodium/Potassium Adenosine Triphosphatase in Multiple Cell Types of the Murine Nervous System with Antibodies Raised Against the Enzyme from Kidney ${ }^{1}$
}

\author{
REGINALD G. ARIYASU, JUDITH A. NICHOL, AND MARK H. ELLISMAN² \\ Laboratory for Neurocytology, Department of Neurosciences, School of Medicine, University of California, San Diego, La Jolla, \\ California 92093
}

\begin{abstract}
This report describes the development and characterization of a battery of highly specific antibodies to sodium/ potassium $\left(\mathrm{Na}^{+}+\mathrm{K}^{+}\right)$-ATPase and their use in localizing this enzyme in nervous tissue. The immunolabeling characteristics of polyclonal antibodies and monoclonal antibodies (Schenk, D. B., and H. L. Leffert (1983) Proc. Natl. Acad. Sci. U. S. A. 80: 5281-5285) raised against rat renal $\left(\mathrm{Na}^{+}+\mathrm{K}^{+}\right)$ATPase were compared. The interspecies cross-reactivity of the polyclonal anti-rat antibodies was examined by determining their binding to purified rat, eel, or dog enzyme. The immunostaining characteristics of the IgG fraction of the polyclonal antibody preparations, their affinity-purified derivatives, and the monoclonal antibodies were compared. The results obtained with each of these were similar, providing information about where focal concentrations of the enzyme exist within nervous tissue. The IgG fraction of the polyclonal antibody preparations provided the most sensitive probe, facilitating localization of the $\left(\mathrm{Na}^{+}+\mathrm{K}^{+}\right)$-ATPase in the tissue sections from various regions of the nervous system.

$\left(\mathrm{Na}^{+}+\mathrm{K}^{+}\right)$-ATPase-like immunoreactivity was observed along the plasmalemma of $\alpha$-motor neurons and at the nodal axolemma of myelinated axons from the central or peripheral nervous system. It was determined that the absence of labeling for the enzyme along the paranodal or internodal regions of the axolemma was not an artifact due to a limited accessibility of antibody to these regions. Some central nervous system glial cells demonstrated abundant amounts of plasmalemmal and intracellular $\left(\mathrm{Na}^{+}+\mathrm{K}^{+}\right)$-ATPase-like im-
\end{abstract}

Received July 5, 1984; Revised February 11, 1985; Accepted March 19, 1985

${ }^{1}$ This work was supported by United States Public Health Service Grant GM07198 to R. G. A., and by United States Public Health Service Grant NS14718 and grants from the Muscular Dystrophy Association and the National Multiple Sclerosis Society to M. H. E. M. H. E. was an Alfred P. Sloan Research Fellow during part of this project. We would like to thank the tollowing for their generous contributions: $D$. Schenck and $H$. Leffert for monoclonal anti- $\left(\mathrm{Na}^{+}+\mathrm{K}^{+}\right)$-ATPase antibodies; $\mathrm{L}$. Eng for anti-GFAP antibodies; I. Kyte for assistance with the purification technique and for anticanine $\left(\mathrm{Na}^{+}+\mathrm{K}^{+}\right)$-ATPase antibodies and the purified canine enzyme; $\mathrm{P}$. A. G. Fortes and J. Lee for providing eel $\left(\mathrm{Na}^{+}+\mathrm{K}^{+}\right)$-ATPase and assisting with its purification; C. A. Wiley for constructive criticism; T. J. Deerinck for preliminary immunocytochemical work and technical assistance; and D. Taitano for assistance with the manuscript.

${ }^{2}$ To whom requests for reprints should be sent munoreactivity. These cells were identified as astroglia by positive labeling of cells in serial sections for glial fibrillary acid protein immunoreactivity in the soma and radial processes in optic nerve, or velous processes in the cerebellum. Astrocyte processes overlying the nodal axolemma also stained positively for the enzyme. $\left(\mathrm{Na}^{+}+\mathrm{K}^{+}\right)$-ATPase-like immunoreactivity was not observed in association with oligodendroglia cell bodies or their processes forming myelin sheaths. In contrast, the plasmalemma of myelinating Schwann cells showed greatest immunoreactivity in the region of the node of Ranvier. Although a focal concentration of immunoreactivity was observed along node- and paranode-associated regions of Schwann cells, a lower level of uniform staining was noted along the entire Schwann cell surface membrane. The significance of the distribution of enzyme determined in these studies is considered with respect to functional significance in regions of focal concentration. The results of the tissue survey and characterization of antibody specificity reported here now enable an assessment of the distribution of $\left(\mathrm{Na}^{+}+\mathrm{K}^{+}\right)$-ATPase in developmental and pathological animal models.

The sodium/potassium-activated adenosine triphosphatase (( $\mathrm{Na}^{+}$ $+\mathrm{K}^{+}$)-ATPase; EC 3.6.1.3.) actively exchanges intracellular sodium ions for extracellular potassium ions (reviewed in Jorgensen, 1982 and Trachtenberg et al., 1981). Activity of $\left(\mathrm{Na}^{+}+\mathrm{K}^{+}\right)$-ATPase significantly influences neuronal excitability by affecting the resting membrane potential of neurons (Thomas, 1972) and maintaining sodium and potassium gradients required for action potential propagation (Bonting, 1970). In addition, the enzyme may also play a role in the uptake of potassium ions by glial cells during periods of intense neuronal activity (Henn et al., 1972; Walz and Hertz, 1982).

Previous studies localizing $\left(\mathrm{Na}^{+}+\mathrm{K}^{+}\right)$-AlPase in various tissues have employed biochemical, autoradiographic, cytochemical, and immunocytochemical techniques (see DiBona and Mills, 1979, and Ernst and Mills, 1980, for reviews). Recently, these techniques have been used to investigate the subcellular distribution of $\left(\mathrm{Na}^{+}+\mathrm{K}^{+}\right)$ ATPase in the nervous system of a number of different species (Wood et al., 1977; Broderson et al., 1978; Sweadner, 1979; Schwartz et al., 1981; Vorbrodt et al., 1982; Siegel et al., 1984; Stahl and Baskin, 1984; among others). A heterogeneous distribution of $\left(\mathrm{Na}^{+}+\mathrm{K}^{+}\right)$-ATPase along the plasmalemma of different cells has been reported by these investigators. For example, the enzyme is concentrated at the inner segment of retinal photoreceptors and along the axolemma of myelinated axons at the node of Ranvier (although limited accessibility of the immunocytochemical reagents 
to the paranodal and internodal regions has not been previously discounted). $\left(\mathrm{Na}^{+}+\mathrm{K}^{+}\right.$)-ATPase prosents some intriguing questions concerning the mechanisms by which its heterogeneous distribution is achieved and maintained. Data revealing the location of functionally specialized regions of cells comprising nervous tissue have potential for providing important insights about the function of a cell and its processes in the overall physiology of the system. To provide this type of data it is first necessary to obtain specific markers for $\left(\mathrm{Na}^{+}+\mathrm{K}^{+}\right)$-ATPase that would allow its localization both intracellularly and within the plasmalemma. These interests and the availability of a number of pathophysiologically interesting rat and mouse mutant models stimulated us to proceed with the development of appropriately sensitive and specific markers for localization studies of $\mathrm{Na}^{+}$ $+\mathrm{K}^{+}$)-ATPase in rat and mouse.

As a result of these endeavors both monoclonal and polycional antibodies against $\left(\mathrm{Na}^{+}+\mathrm{K}^{+}\right)$-ATPase were produced and have proven to be highly accurate probes of the enzyme both in vitro and in situ. Descriptions of the monoclonal antibody preparations' specificity for rat renal $\left(\mathrm{Na}^{+}+\mathrm{K}^{+}\right)$-ATPase in vitro have been reported elsewhere (Schenk and Leffert, 1983; Schenk et al., 1984). In the present report we first provide a detailed description of experiments involved in the production and characterization of polyclonal antibodies against rat renal $\left(\mathrm{Na}^{+}+\mathrm{K}^{+}\right)$-ATPase. This is followed by the results of experiments using both polyclonal and monoclonal antibodies to immunocytochemically localize the enzyme in the CNS and PNS of rats and mice. Portions of this work have been previously communicated in abstract form (Ariyasu et al., 1982).

\section{Materials and Methods}

\section{Enzyme purification}

The $\left(\mathrm{Na}^{+}+\mathrm{K}^{+}\right)$-ATPase was purified from the renal medulla of rats and the electric organ of Electrophorus electricus. Purified canine renal $\left(\mathrm{Na}^{+}+\right.$ $\mathrm{K}^{+}$)-ATPase was the generous gift of $\mathrm{J}$. Kyte. (Some of the purified eel ATPase, used to produce antibodies at the outset of these studies, was a gift of P. A. G. Fortes.) The method used to purify the rat enzyme was that of Kyte (1971), a modification of the method of Jorgensen and Skou (1969). Microsomes were solubilized with sodium lauryl sulfate (SDS) as described by Jorgensen (1974). The optimal SDS concentration was determined individually for each microsome preparation. Purification of $\left(\mathrm{Na}^{+}+\mathrm{K}^{+}\right)$-ATPase frurr rricrosomes was performed according to the method of Winslow (1981). Eel enzyme was purified by the method of Dixon and Hokin (1978). Enzyme activity was assayed as described by Kyte (1971) except that phosphatidylL-serine was not included in the assay mixture. Protein concentrations were determined by the method of Lowry et al. (1951).

SDS-polyacrylamide slab gels were run according to the method of Laemmli (1970). Gels were stained with Coomassie blue-R250 and were scanned using either a Beckman Du8 spectrophotometer with a slab gel scanning accessory or a Quick Scan R and D. Gels were also silver stained using the protocol of Morrissey (1981). In order to purify the individual subunits, a strip was cut from the preparative gels and stained to locate the bands to be eluted. The remainder of the gel was frozen until the bands were excised. The protein was electroeluted from the gel slices using a CBS Scientific electroelution apparatus (Del Mar, CA) and dialyzed against buffer and DOWEX $1-X 8$ to remove the free SDS. The purified subunits were stored at -20 or $-85^{\circ} \mathrm{C}$.

\section{Antibody production, purification, and characterization}

Antibodies were raised against rat and eel holoenzymes and the $\alpha$-and $\beta$ subunits of the rat enzyme by identical methods. Antibodies were produced in female, white New Zealand rabbits. The rabbits were initially injected with $100 \mu \mathrm{g}$ of protein in Freund's complete adjuvant. Booster injections were 20 to $50 \mu \mathrm{g}$ of protein in Freund's complete adjuvant at 1 - to 3 -month intervals. The rabbits were bled 10 to 14 days after booster injections. A portion of the sera was precipitated with ammonium sulfate and passed down a DEAE. cellulose column to partially purify the $\operatorname{lgG}$ fraction. Some preparations were further purified by protein A column chromatography. DEAE-purified antibodies were loaded onto the column at $4^{\circ} \mathrm{C}$ for 1 to 2 days. After washing off excess antibodies, "bound" antibodies were eluted with $0.2 \mathrm{M} \mathrm{HCl}$ adjusted to $\mathrm{pH} 2.8$ with glycine. The eluate was immediately brought to $\mathrm{pH} 7$. The purified antibodies were dialyzed against phosphate-buffered saline $(\mathrm{pH} 7.2)$ and concentrated.
Antibodies were affinity purified using a method adapted from Ternynck and Avrameas (1976) by I ouvard (1980). The antigen (enzyme) was loaded on a concanavalin $\mathrm{A}$ (con $\mathrm{A}$ )-Sepharose $4 \mathrm{~B}$ column and then left for 3 days at $4^{\circ} \mathrm{C}$. The column was washed and unreacted sites were neutralized with ovalbumin. The antigen-con A-Sepharose complexes were fixed with $0.5 \%$ glutaraldehyde for $1 / 2 \mathrm{hr}$ and unreacted aldehyde was neutralized with lysine. DEAE-purified antibodies were loaded onto the column at $4^{\circ} \mathrm{C}$ for 2 to 4 days. Affinity-purified antibodies were collected and concentrated following the method outlined above. The antibody titers and antigen binding specificity were examined by the enzyme-linked immunosorbent assay (ELISA) described below. The antibodies were aliquoted and stored at -20 or $-85^{\circ} \mathrm{C}$.

The ELISAs were carried out in Linbro/Titer 96 multiwell plates. The indirect ELISA was used to titer the sera and to show the specificity of the antibody for the antigens. The method used was that initially described by Engvall and Perlmann (1972) and further described by Voller et al., (1979), using horseradish peroxidase conjugated to goat anti-rabbit IgG and $O$-phenylenediamine as the substrate to visualize the amount of primary antibody binding.

Antibodies to be used as blocked controls were incubated with a minimum of $5 \mu \mathrm{g}$ of ATPase $/ \mathrm{ml}$ of sera for $3 \mathrm{hr}$ at $37^{\circ} \mathrm{C}$. All blocked antibodies were tested by ELISA to ensure that they were fully blocked. The ratio of the binding capacity of experimental preparations to absorbed control preparations were estimated from ELISA using the following formula: $10^{(x-z)(y-z)}$ where $x, y$, and $z$ are the $\log$ antibody dilutions corresponding to the halfmaximal optical density at $490 \mathrm{~nm}$ for the experimental, absorbed control, and normal rabbit serum preparations, respectively.

Proteins from analytical gels were transferred electrophoretically onto nitrocellulose paper by the "blotting" or protein transfer method of Towbin et al., (1979). Some blots were stained by the method of Burnette (1981) with Coomassie blue to show transfer of the protein. To show immunospecificity, blots were incubated with the various antibodies. Antibody-antigen binding was visualized either by ${ }^{125}-1$-protein $A$, by peroxidase-antiperoxidase (PAP), or by biotinylated goat anti-rabbit followed by peroxidase avidin, using the substrates 3-amino-9-ethylcarbazole or 4-chloro-1-napthol.

Antibodies against canine renal $\left(\mathrm{Na}^{+}+\mathrm{K}^{+}\right)$-ATPase were provided by $\mathrm{J}$. Kyte (see Kyte, 1976a, b). Monoclonal antibodies against rat ronal $\left(\mathrm{Na}^{+}+\right.$ $\mathrm{K}^{+}$)-ATPase were generously donated by $\mathrm{D}$. Schenk and $\mathrm{H}$. Leffert (see Schenk and Leffert, 1983). Antibodies against glial fibrillary acid protein (GFAP) were the generous gift of L. Eng (see Eng et al., 1971; Uyeda et al., 1972).

\section{Immunocytochemical procedures}

Fixation. Adult Sprague-Dawley rats (Charles River Breeding Laboratories, Wilmington, MA) and 129 ReJ mice (Jackson Laboratories, Bar Harbor, ME) were anesthetized with Nembutal $(1 \mathrm{ml} / \mathrm{kg}$, i.p.) and perfused through the heart. Rat Ringer's solution at $37^{\circ} \mathrm{C}$ was followed by fixative which was cooled from $37^{\circ} \mathrm{C}$ to $10^{\circ} \mathrm{C}$ during the perfusion. Three different fixatives were employed: (1) periodate-tysine-paraformaldehyde (PLP) fixative (McLean and Nakane, 1974), (2) modified PLP fixative $(0.55 \mathrm{gm} /$ liter of sodium periodate, $3.4 \mathrm{gm} /$ liter of mono-DL lysine, $4 \%$ paraformaldehyde), and (3) $4 \%$ paraformaldehyde with different concentrations of glutaraldehyde $(0.10 \%, 0.25 \%$, $0.50 \%, 1.0 \%, 1.5 \%$ ). Tissue was dissected and immersion fixed for an additional hour at $4^{\circ} \mathrm{C}$. Qualitatively and quantitatively, staining patterns observed with these fixatives appeared identical.

Preparation of tissue for light microscopy. Spinal roots and spinal cords were incubated in collagenase type IV ( $1 \mathrm{mg} / \mathrm{ml}$; Sigma Chemical Co., St. Louis, MO) and hyaluronidase, type $1-\mathrm{S}(1 \mathrm{mg} / \mathrm{ml}$; Sigma), solutions for 30 min each at $4^{\circ} \mathrm{C}$. Teased preparations of spinal roots were done on freshly fixed tissue. Tissue to be sectioned was first cryoprotected by incubation in solutions of increasing sucrose/glycerol $(4 \% / 2 \%, 8 \% / 4 \%, 12 \% / 6 \%, 16 \% /$ $8 \%, 20 \% / 10 \%$ ) for 15 min each. Cryoprotected tissue was frozen in liquid nitrogen-cooled freon and stored in liquid nitrogen-cooled Krocs. Tissue was frozen sectioned on a Damon/EC Division Minitome. Teased roots or sections were picked up on warm slides coated with poly-L-lysine. Antibody incubations on glass slides followed the protocol of Sanes and Hill (1979). Primary antibody incubations were for $1 \mathrm{hr}$ at room temperature or overnight at $4^{\circ} \mathrm{C}$ with $1 \%$ normal serum. Tissue was washed (all washes were done in $50 \mathrm{~mm}$ Tris buffer, $\mathrm{pH} 7.2$, four times, for 5 min each at $4^{\circ} \mathrm{C}$ ) and secondary antibodies were incubated for $1 \mathrm{hr}$ at room temperature followed by a wash. Immunofluorescently labeled preparations were coverslipped in $90 \%$ glycerol mounting medium and viewed with a Zeiss Universal microscope equipped for epi-fluorescence. Tissue for the immunoperoxidase technique was incubated in the PAP solution. After a wash, sections were pretreated in $50 \mathrm{mg} /$ $100 \mathrm{ml}$ of diaminobenzidine for 5 minutes followed by an incubation in DAB with $0.015 \% \mathrm{H}_{2} \mathrm{O}_{2}$ for 5 to $10 \mathrm{~min}$. The tissue was washed, dehydrated, and 
delipidated following standard protocols, coverslipped, and viewed with brightfield or phase contrast optics.

Preparation of tissue for immunoelectron microscopy. Fixed pieces of tissue were Vibratome sectioned into $50-\mu \mathrm{m}$-thick slices. Sections were incubated in primary antiserum or control solutions for $1 \mathrm{hr}$ at room temperature or overnight at $4^{\circ} \mathrm{C}$, and washed in buffer (all washes were done six times for $10 \mathrm{~min}$ each at $4^{\circ} \mathrm{C}$ with agitation). Incubation in secondary antisera was for $1 \mathrm{hr}$ at room temperature followed by a wash. Incubation in PAP solution was for $1 \mathrm{hr}$ at room temperature. After a wash, the peroxidase reaction was performed (see above). Tissue was washed, fixed with $2 \%$ osmium tetroxide for $1 \mathrm{hr}$, and dehydrated and embedded in Epon/Araldite resin following conventional techniques. Tissue was sectioned on an LKB or an $\mathrm{AO}$ Reichert Ultracut microtome, and viewed on a JEOL $100 \mathrm{~B}$ or $100 \mathrm{CX}$ electron microscope at 60 or $80 \mathrm{keV}$.

\section{Results}

\section{Enzyme purification, antibody preparation, and characterization}

Monoclonal antibody preparation and characterization have been described previously (Schenk and Leffert, 1983; Schenk et al., 1984). These reports showed that the two monoclonal antibodies employed in this study, 9A5 and 9B1, bind to the $\alpha$-subunit and inhibit $\left(\mathrm{Na}^{+}+\right.$ $\mathrm{K}^{+}$)-ATPase activity in rat and kidney liver membrane. These monoclonal antibodies were used in immunocytochemical localization experiments to investigate the cellular distribution of $\left(\mathrm{Na}^{+}+\mathrm{K}^{+}\right)$ATPase and to verify further the tissue specificity of the polyclonal antibody preparations.

Polyclonal antibodies were raised in several rabbits against the holo- $\left(\mathrm{Na}^{+}+\mathrm{K}^{+}\right)$-ATPase and the individual subunits. In order to obtain highly specific polyclonal antibodies against $\left(\mathrm{Na}^{+}+\mathrm{K}^{+}\right)$ATPase, the use of highly purified enzyme as the inoculating antigen was essential. The native holoenzyme and its constituent subunits were purified to apparent homogeneity from rat renal medulla. Specific activities of the purified holoenzyme were 500 to $2,000 \mu \mathrm{M}$ $\mathrm{P}_{1}$ liberated/mg of protein/hr, consistent with previously reported values of highly purified preparations (Hopkins et al., 1976; Peterson et al., 1978). When examined using SDS-PAGE with either Coomassie blue or silver staining, partially purified microsomal preparations used in Western blots (see below) showed a number of other proteins in addition to the $\alpha$ - and $\beta$-subunits of $\left(\mathrm{Na}^{+}+\mathrm{K}^{+}\right)$-ATPase (Fig. 1, lane 1). SDS-PAGE of purified preparations of the holoenzyme revealed two major bands of $M_{r}=97,000$ and $M_{r}=56,000$ (Fig. 1, lane 2). These values are withirn the published range of molecular weights for the $\alpha$ - and $\beta$-subunits of $\left(\mathrm{Na}^{+}+\mathrm{K}^{+}\right)$-ATPase (Craig and Kyte, 1980). The absence of other bands suggested that contaminating proteins were not present. Highly purified $\alpha$ - and $\beta$ subunits were also prepared by electroelution from SDS-polyacrylamide gels. When examined by SDS-PAGE, each of the purified subunits showed only one distinct band (Fig. 1, lanes 3 and 4). There was no apparent contamination of the purified subunit with the other subunit of the enzyme or with other proteins. These purified preparations of the holoenzyme, and the $\alpha$ - and $\beta$-subunits, were used to raise polyclonal antibodies. Anti-holoenzyme antibodies proved most useful for immunolocalization experiments, whereas anti-subunit antibodies were used principally for analytical purposes to determine the purity and specificity of other enzyme preparations.

Characterization of these polyclonal antibody preparations for $\left(\mathrm{Na}^{+}+\mathrm{K}^{+}\right)$-ATPase employed ELISAs (Fig. 2, 4, and 5) and Western blots (Fig. 3). The affinity of the anti-holoenzyme preparation for $\left(\mathrm{Na}^{+}\right.$ $+\mathrm{K}^{+}$)-ATPase was considerably greater than that of normal rabbit serum as measured by ELISA (Fig. 2). Binding activity of control preparations of the anti-holoenzyme antibody, preadsorbed with antigen, were reduced to levels comparable to those for normal serum. The affinity of the anti-holoenzyme preparations for $\left(\mathrm{Na}^{+}+\right.$ $\mathrm{K}^{+}$)-ATPase was approximately 600 times the level associated with the preabsorbed control preparation (see "Materials and Methods"). Experimental and control antibody preparations employed in each biochemical and immunocytochemical experiment were always from the same bleed from the same rabbit.
Affinity of the different polyclonal antibodies for various enzyme preparations was examined using immunoblotting techniques (Fig. 3). Anti-holoenzyme antibodies recognize both the $\alpha$ - and $\beta$-subunits (Fig. $3 A$, lanes 1 to 4 ). The absence of detectable binding to other proteins in partially purified microsomal preparations (Fig. 3A, lane 4) demonstrated that the anti-holoenzyme preparations are highly specific for $\left(\mathrm{Na}^{+}+\mathrm{K}^{+}\right)$-ATPase. Occasionally, there was light staining of the track below the $\alpha$-band. Since this was also present in the blot incubated with the anti- $\alpha$ serum but not the anti- $\beta$ serum, we interpreted these bands to represent fragments of the $\alpha$-subunit. The anti- $\alpha$ and anti- $\beta$ antibodies showed binding only to the appropriate subunit and did not cross-react with the other subunit (Fig. 3, $B$ and $C$ ). Anti- $\alpha$ antibodies bind to the band corresponding to the $\alpha$-subunit (Fig. 3B, lanes 1 to 3). No binding to the band corresponding to the $\beta$-subunit was detected with the anti- $\alpha$ antisera (Fig. $3 B$, lanes 1 and 3 ). Blots incubated with anti $\beta$ serum showed staining only of the band corresponding to the $\beta$-subunit, with no staining of the $\alpha$-subunit (Fig. 3C, lanes 1 to 3). Normal rabbit serum did not bind to bands corresponding to either subunit (Fig. 3D, lanes 1 to 3).

Determining the relative affinities of the anti- $\alpha$, anti- $\beta$ and antiholoenzyme antibodies for the purified $\alpha$ - and $\beta$-subunits and the holoenzyme required examination using ELISAs (Fig. 4). Results showed that the anti-subunit antisera had high affinity for the subunit for which they had been raised, with very little binding to the other subunit (Fig. 4, $A$ and $B$ ). Anti- $\alpha$ antibodies had the highest affinity for the $\alpha$-subunit, with slightly lower binding to the holoenzyme and little recognition of the $\beta$-subunit. Anti- $\beta$ antibodies had the highest affinity for the purified $\beta$-subunit, with a slightly lower binding to the holoenzyme, and little recognition of the $\alpha$-subunit. The anti-holoenzyme antibodies had the highest binding to the holoenzyme, followed by the $\beta$ and then the $\alpha$ subunit (Fig. 4C).

The results of ELISAs and Western blots demonstrated that the anti-holoenzyme, anti- $\alpha$, and anti- $\beta$ polyclonal antibody preparations had high affinity for $\left(\mathrm{Na}^{+}+\mathrm{K}^{+}\right)$-ATPase and the (appropriate) $\alpha$-and $\beta$-subunits. Since the affinity of an antibody for an antigen gives a measure of the specificity of the antibody for that antigen (Sternber ger, 1979, p. 15), these results suggested that these antibody preparations are highly specific. The availability of these antibodies, as well as high affinity antibodies against dog and eel $\left(\mathrm{Na}^{+}+\mathrm{K}^{+}\right)$ATPase allowed us to examine the degree of cross-reactivity between anti-( $\left.\mathrm{Na}^{+}+\mathrm{K}^{+}\right)$-ATPase preparations raised in various species. The affinity of polyclonal antibodies raised against $\left(\mathrm{Na}^{+}+\mathrm{K}^{+}\right)$. ATPase from rat, dog, and eel for these proteins was compared by ELISA (Fig. 5). Each antiserum was most specific tor its homologous antigen. Rat and dog had intermediate levels of cross-reactivity when compared to results obtained with their homologous antibodyantigen combinations (Fig. 5, $A$ and $B$ ). Eel had insignificant crossreactivity with rat and $\operatorname{dog}$ ( $\mathrm{Fig} .5, A$ to $C$ ). The results of these experiments justified, in our minds, our efforts to raise specific antibodies against rat $\left(\mathrm{Na}^{+}+\mathrm{K}^{+}\right)$-ATPase for use in immunocytochemical experiments in rats and mice.

\section{Localization of $\left(\mathrm{Na}^{+}+K^{+}\right)$-ATPase by immunocytochemistry}

Initial immunocytochemical screenings of the monoclonal and polyclonal antibodies were done on rat renal tissue to determine their usefulness in localization studies. The anti- $\alpha$ and anti- $\beta$ polyclonal antibody preparations revealed limited recognition of the enzyme in rat kidney and optic nerve (data not shown). One possible explanation is that these antibodies are directed primarily at epitopes on denatured portions of each subunit that arose during purification by SDS PAGE. Thesc results demonstrated that antibodies raised against denatured antigens, although useful biochemically, may not have high affinity for the antigen as found in tissue. Monoclonal and anti-holoenzyme antibodies did recognize $\left(\mathrm{Na}^{+}+\mathrm{K}^{+}\right)$-ATPase in initial screenings, and these preparations were employed in this investigation. Three different polyclonal anti-holoenzyme antibody preparations, purified by DEAE-cellulose, protein $\mathrm{A}$, or $\left(\mathrm{Na}^{+}+\mathrm{K}^{+}\right)$ 

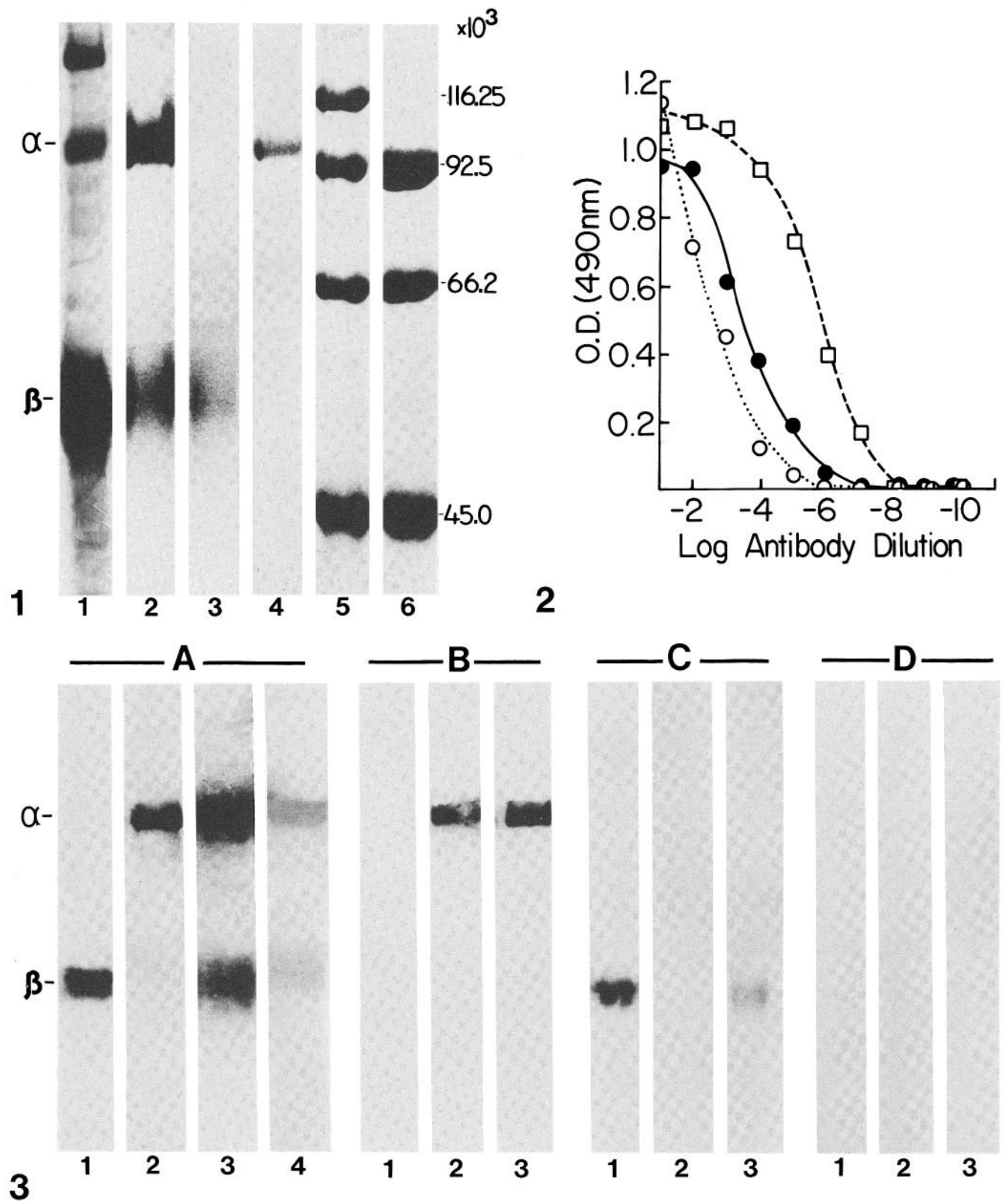

Figure 1. SDS-polyacrylamide gel of preparations of purified rat renal $\left(\mathrm{Na}^{+}+\mathrm{K}^{+}\right)$-ATPase. Lane 1, Microsomal preparation; lane 2, purified holoenzyme. The higher molecular weight band corresponds to the $\alpha$-subunit. The lower molecular weight band corresponds to the $\beta$-subunit and was diffuse, a characteristic of glycoproteins run on SDS-polyacryamide gel, (Kyte, 1972); see also lane 3, Gel-purified $\beta$-subunit; lane 4, gel-purified $\alpha$-subunit; lanes 5 and 6, molecular weight standards.

Figure 2. A representative ELISA comparing the binding activity of experimental $(\square)$ and preabsorbed control preparations $(\bullet)$ with normal rabbit serum $(O)$ for the purified holoenzyme preparation. ELISAs measure antibody binding to antigen in units of optical density (O.D.) at $490 \mathrm{~nm}$.

Figure 3. Western blot examining the specificity of the antibodies raised against the purified holoenzyme and the $\alpha$ - and $\beta$-subunits. Lanes 1 and 2 show, respectively, the gel-purified $\beta$-subunit and the $\alpha$-subunit, rerun by SDS-PAGE and transferred to nitrocellulose paper. Lane 3 shows the purified holoenzyme preparation run by SDS-PAGE and transferred to nitrocellulose paper. Lane 4 shows the partially purified microsomal preparation run by SDS-PAGE and transferred to nitrocellulose paper. Anti-holoenzyme antibodies were used in $A$, anti- $\alpha$ antibodies were used in $B$, anti- $\beta$ antibodies were used in $C$, and normal rabbit serum was used in $D$. 


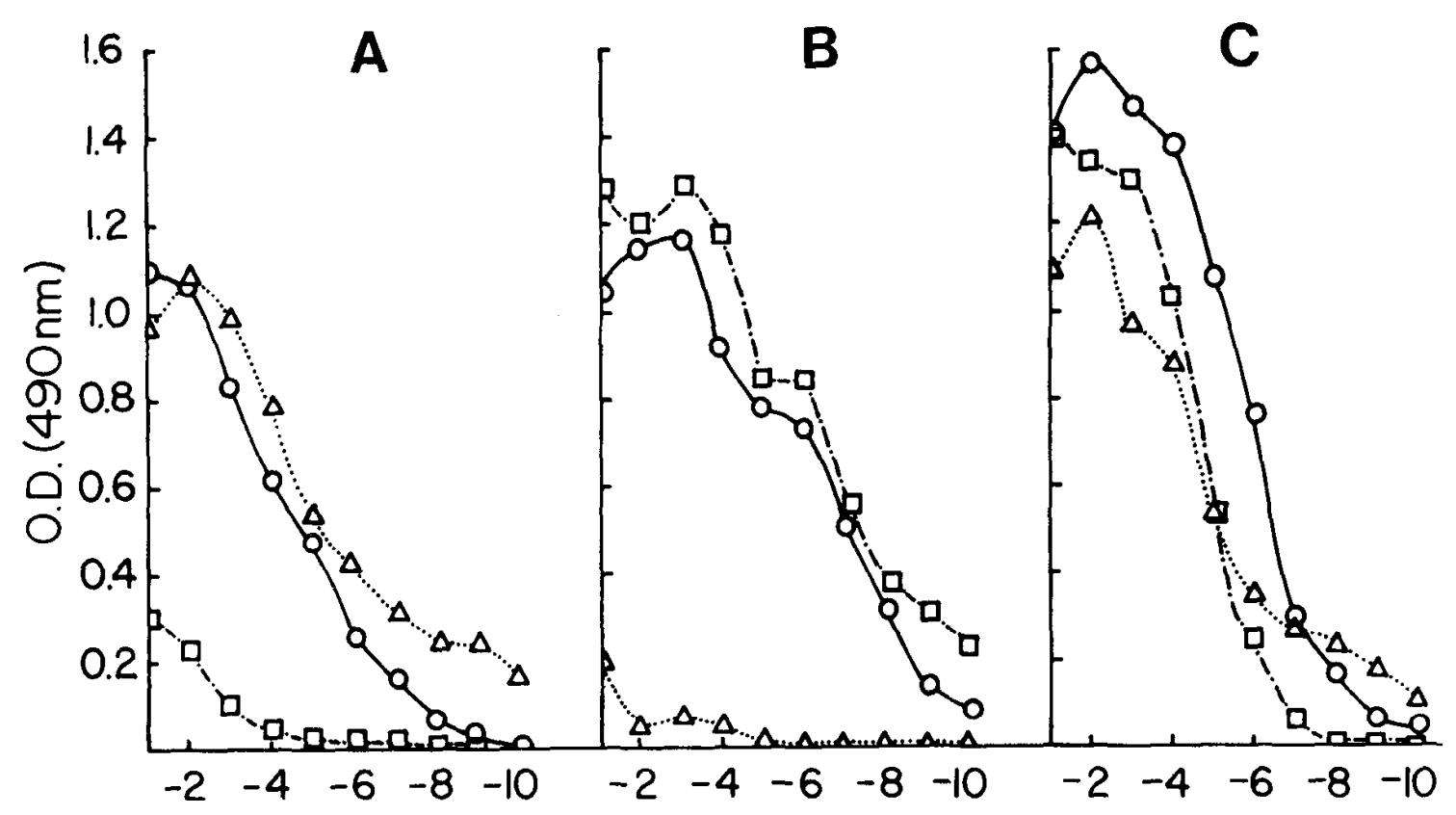

\section{Log Antibody Dilution}

4

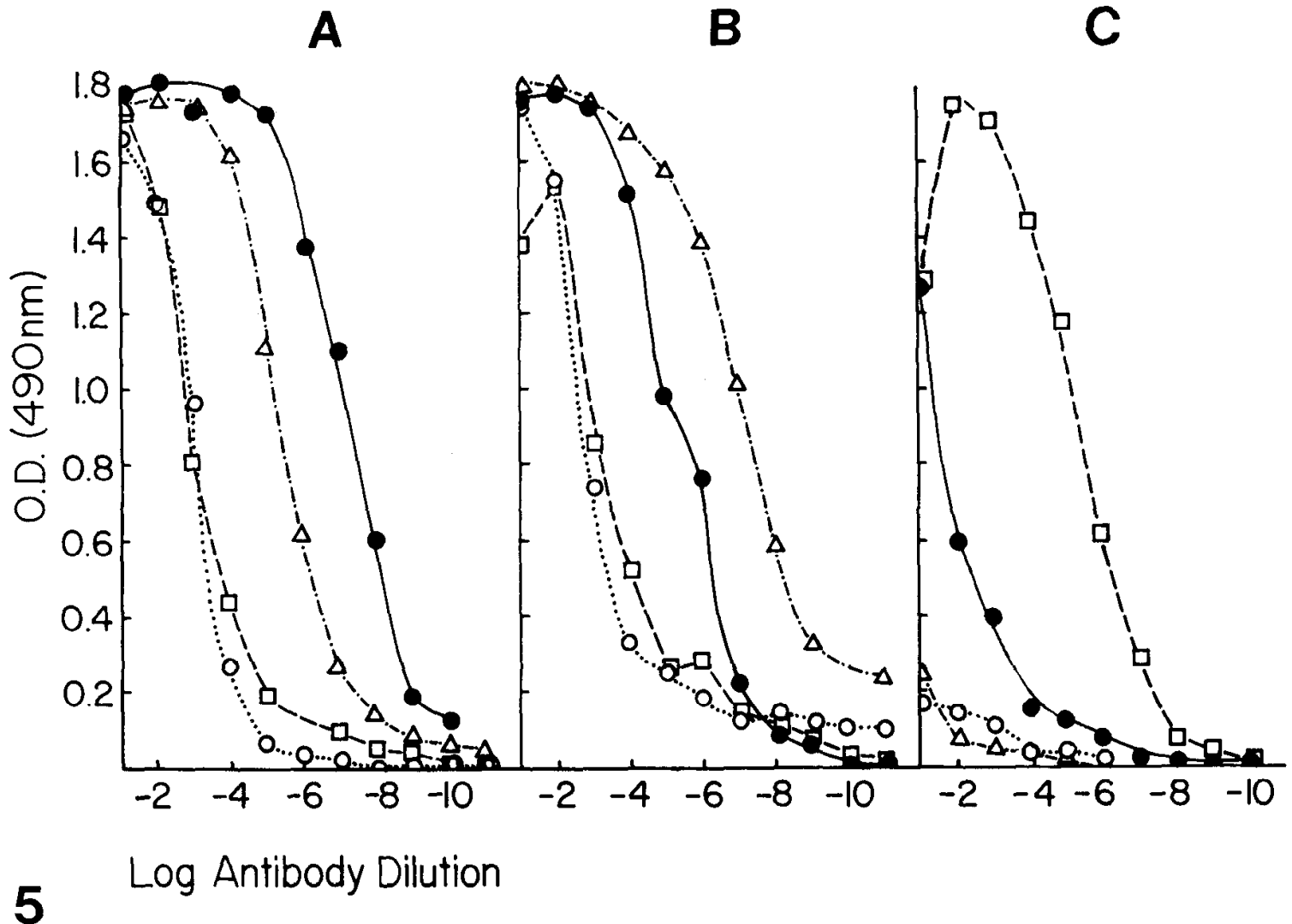

Figure 4. ELISAs are a method for evaluating the relative affinities of the anti-holoenzyme, anti- $\alpha$, and anti- $\beta$ antibodies for the purified holoenzyme and subunits. Data were obtained with the anti- $\alpha$ antibodies $(\triangle)$, anti- $\beta$ antibodies $(\square)$, and the anti-holoenzyme antibodies $(O)$, using as antigen the gel-purified $\alpha$-subunit $(A)$, the $\beta$-subunit $(B)$, or the purified holoenzyme $(C)$.

Figure 5. ELISAs showing species cross-reactivity between rat, canine, and eel $\left(\mathrm{Na}^{+}+\mathrm{K}^{+}\right)$-ATPase and antibodies raised against these enzymes. Results were obtained with polyclonal antibodies raised against the purified holoenzyme from rat $(\mathbf{O}), \operatorname{dog}(\triangle)$, eel $(\square)$, and normal rabbit serum (NRS) (O) to purified holoenzyme from rat $(A), \operatorname{dog}(B)$, or eel $(C)$. $A$, When compared to NRS controls binding to rat holoenzyme was greatest with anti-rat antibudies, intermediate with anti-dog antibodies, and negligible with anti-eel antibodies. $B$, when compared to NRS controls, binding to canine holoenzyme was greatest with anti-canine antibodies, intermediate with anti-rat antibodies, and negligible with anti-eel antibodies. C. When compared to NRS controls, binding to eel holoenzyme was greatest with anti-eel antibodies, intermediate with anti-rat antibodies, and negligible with anti-canine antibodies. 

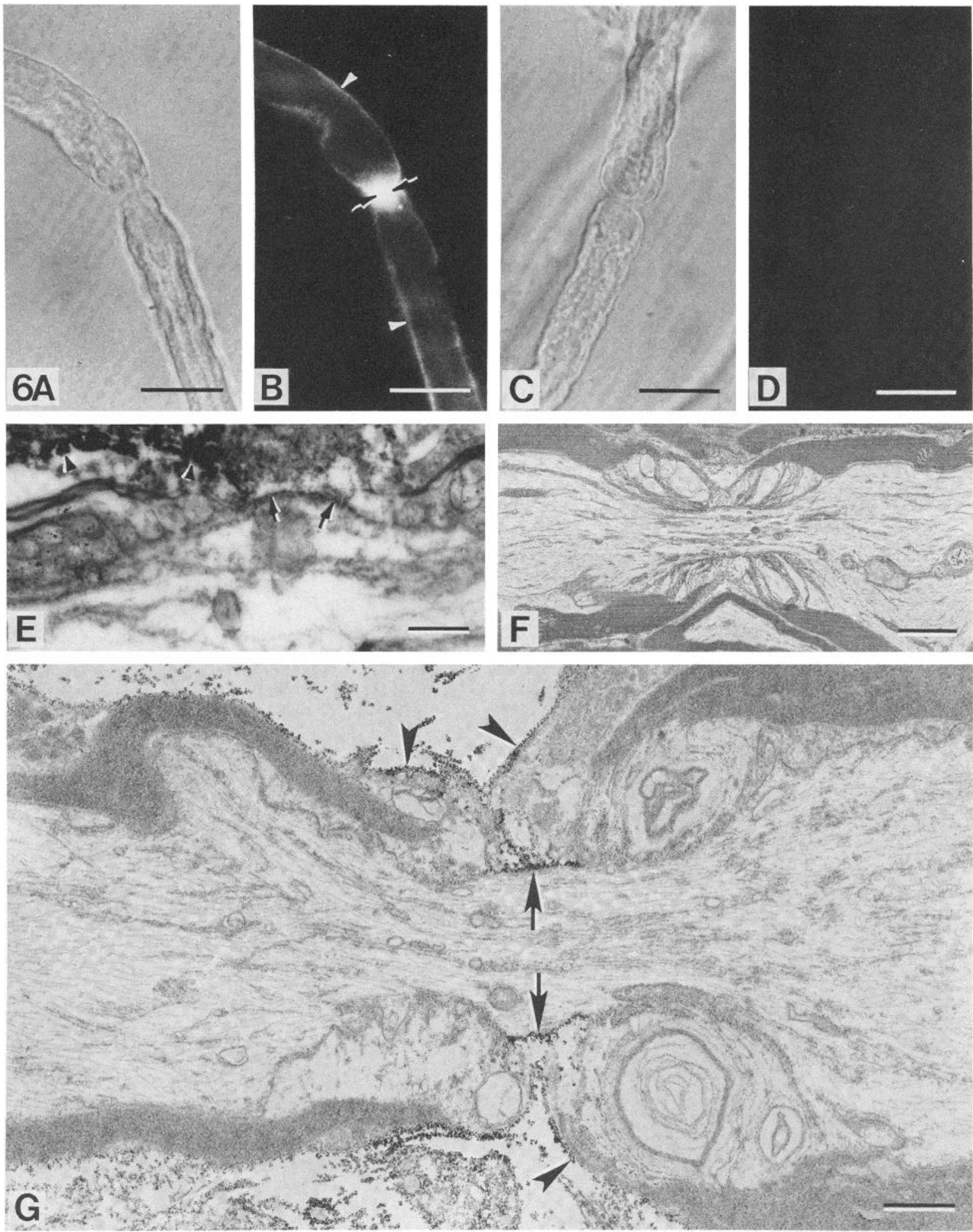

Figure 6. $\left(\mathrm{Na}^{+}+\mathrm{K}^{+}\right)$-ATPase immunoreactivity in myelinated axons. $A$ to $D$, Myelinated axons teased from a rat spinal root. $A$, Brightfield image of an experimental preparation. Bar $=10 \mu \mathrm{m}$. B. Corresponding immunofluorescent image of the myelinated axon in $A$. Note the intense nodal axolemmal staining (arrows). The plasmalemma of Schwann cells is also stained (arrowheads). C, Brightfield image of an absorbed control preparation. D, Corresponding immunofluorescent image of the myelinated axon in $C$. Note the absence of staining. $E$, Immunoelectron microscopy of a myelinated axon from rat optic nerve. Immunoreactivity was observed at the node of Ranvier (arrows). Note the heavily stained astrocyte process (see below), which lies in the extracellular space around the node of Ranvier (arrowheads). Mildly treated with Lubrol PX. Bar $=0.25 \mu \mathrm{m}$. $F$, Immunoelectron microscopy of an absorbed control preparation from mouse spinal root. Staining was not observed in these preparations. Bar $=3 \mu \mathrm{m}$. G, Immunoelectron microscopy of myelinated axons from mouse spinal root. Immunoreactivity was restricted to the nodal axolemma (arrows) and the Schwann cell plasmalemma (arrowheads). Bar $=1 \mu \mathrm{m}$. 
ATPase affinity column chromatography, were used. All three yielded similar qualitative and quantitative results and, unless otherwise noted, the results reported have employed DEAE-cellulose column chromatographed preparations.

Although substantial biochemical evidence suggested that both the monoclonal and polyclonal antibody preparations are highly specific for $\left(\mathrm{Na}^{+}+\mathrm{K}^{+}\right)$-ATPase, additional evidence was necessary to establish that these probes are specific for the enzyme in tissue. The best measure of tissue specificity of an antibody preparation is to compare results obtained with other examples in the literature (Sternberger, 1979, p. 148). Thus, as the final measure of the specificity of both the monoclonal antibodies and polyclonal antibodies, the data obtained in this study were compared with previously reported results from a number of different species (rat, mouse, Sternarchus, chicken, and goldfish) using a variety of techniques (immunocytochemistry, autoradiography, and cytochemistry). Based on these comparisons, these probes were determined to be highly specific for $\left(\mathrm{Na}^{+}+\mathrm{K}^{+}\right)$-ATPase in tissue and were used to investigate further the distribution of the enzyme along the axolemma of myelinated axons, and in glial cells.

Neuronal cells. Neuronal $\left(\mathrm{Na}^{+}+\mathrm{K}^{+}\right)$-ATPase immunoreactivity was observed on the nodal axolemma and on the somal plasmalemma of neurons. Myelinated axons from the spinal roots of rats and mice and the optic nerve of rats demonstrated significant $\left(\mathrm{Na}^{+}\right.$ $+\mathrm{K}^{+}$)-ATPase immunoreactivity along the axolemma only at the node of Ranvier (Fig. 6). Absorbed control preparations showed that this result was specific for $\left(\mathrm{Na}^{+}+\mathrm{K}^{+}\right)$-ATPase (Fig. 6, $D$ and F). Similar reports of nodal axolemmal $\left(\mathrm{Na}^{+}+\mathrm{K}^{+}\right)$-ATPase have been communicated by Wood et al. (1977) in Sternarchus and by Schwartz et al. (1981) in goldfish optic nerve. In a separate experiment, the paranodal and internodal axolemma were exposed to remove barriers to immunocytochemical reagents prior to incubation with anti-( $\left.\mathrm{Na}^{+}+\mathrm{K}^{+}\right)$-ATPase solutions (Fig. 7). This was achieved by vigorous Vibratome sectioning of rat spinal cord in a calcium-free buffer. Whereas the nodal axolemma of the "demyelinated" axons was heavily stained, $\left(\mathrm{Na}^{+}+\mathrm{K}^{+}\right)$-ATPase-like immunoreactivity was not observed in the exposed internodal or paranodal regions of axons. Control preparations, treated identically except for vigorous Vibratome sectioning, showed little desheathing of axons (data not shown).

Experimental preparations of rat spinal cord demonstrated apparently continuous immunocytochemical reactivity along the plasmalemma of $\alpha$-motor neurons by immunoelectron microscopy (Fig. 8). Absorbed control preparations demonstrated that this staining was specific for our purified $\left(\mathrm{Na}^{+}+\mathrm{K}^{+}\right.$)-ATPase (data not shown). Neuronal plasmalemmal $\left(\mathrm{Na}^{+}+\mathrm{K}^{+}\right)$-ATPase has also been observed immunocytochemically by Wood et al. (1977) in Sternarchus telencephalon and in mouse cerebellum (Siegel et al., 1984). Cytochemical studies have reported $\left(\mathrm{Na}^{+}+\mathrm{K}^{+}\right)$-ATPase in association with the plasmalemma of dendrites (Broderson et al., 1978; Inomata et al., 1983; Nasu, 1983) but not the plasmalemma of neuronal somata (Inomata et al., 1983).

Glial cells. Glial $\left(\mathrm{Na}^{+}+\mathrm{K}^{+}\right)$-ATPase immunoreactivity was observed in astrocytes and Schwann cells but not in oligodendrocytes, using both polyclonal and monoclonal antibody preparations. Fibrous and protoplasmic astrocytes including their processes showed significant amounts of plasmalemmal and intracellular $\left(\mathrm{Na}^{+}+\mathrm{K}^{+}\right)$ATPase immunoreactivity. Experiments in cross-sections and longitudinal sections of rat optic nerve showed glial cells heavily stained for $\left(\mathrm{Na}^{+}+\mathrm{K}^{+}\right)$-ATPase (Fig. 9 to 11). The identification of these cells as astrocytes was accomplished by staining adjacent sections in a series of cross-sections with antibodies against $\left(\mathrm{Na}^{+}+\mathrm{K}^{+}\right)$-ATPase or GFAP (Fig. 9). The results obtained demonstrated that cells positively labeled for $\left(\mathrm{Na}^{+}+\mathrm{K}^{+}\right)$-ATPase (Fig. 9A) were also GFAP immunoreactive (Fig. $9 B$ ), thus identifying these cells as astrocytes (Eng and DeArmond, 1981). There is little $\left(\mathrm{Na}^{+}+\mathrm{K}^{+}\right)$-ATPase-like
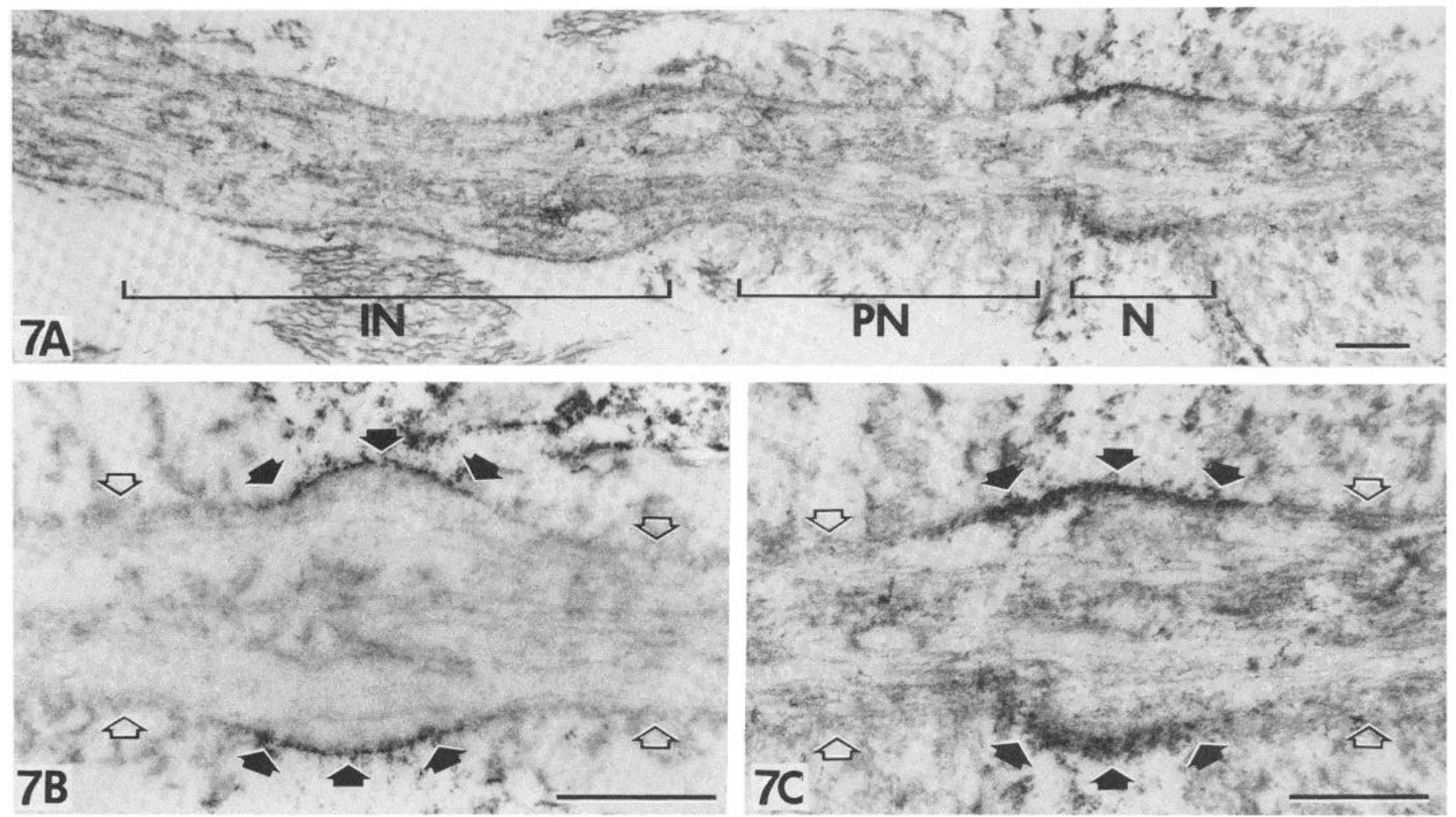

Figure 7. Electron microscopy of axons from rat spinal cord, vigorously Vibratome sectioned prior to incubation in the primary antibody. A, lower magnification of a "demyelinated," stained axon. Significant $\left(\mathrm{Na}^{+}+\mathrm{K}^{+}\right)$-ATPase immunoreactivity was observed only at presumptive nodes of Ranvier $(N)$ and was absent in the adjacent paranodal region $(P N)$ and internodal region $(I N)$. B and $C$. Higher magnifications showing staining in the nodal (solid arrows) but not the paranodal regions (open arrows). $B$, Another demyelinated axon. $C, A$ higher magnification of the axon shown in $A$. Bar $=1.0 \mu \mathrm{m}$. 


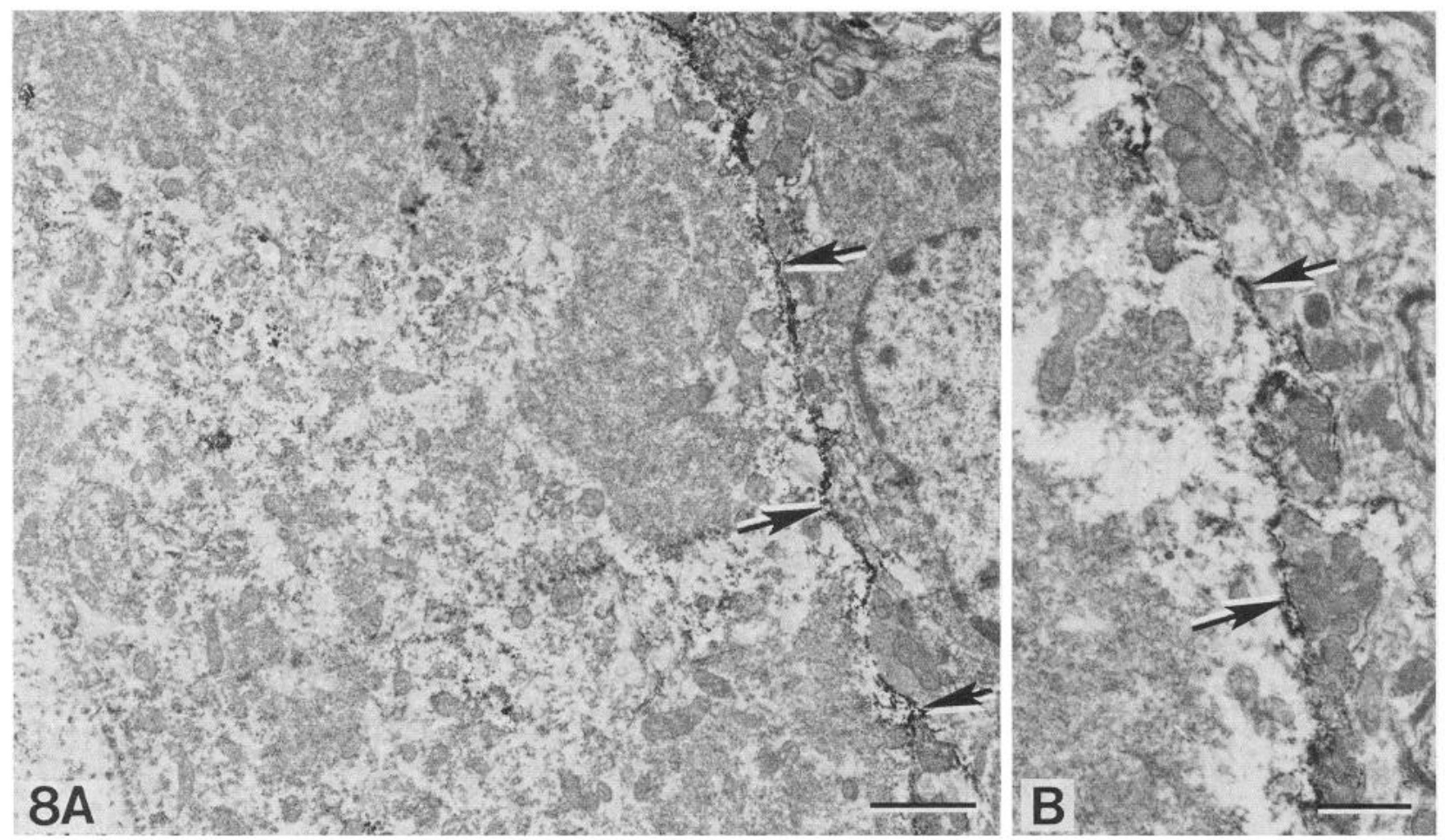

Figure 8. Immunoperoxidase reactivity of $\alpha$-motor neurons from rat spinal cord. Reaction product was present along the plasmalemma (arrows). A, Lower magnification. Bar $=2 \mu \mathrm{m}$. B. Higher magnification of a different $\alpha$-motor neuron showing greater detail of the plasmalemmal staining. Bar $=1 \mu \mathrm{m}$.

immunoreactivity in these cells when incubated with antibodies preabsorbed with $\left(\mathrm{Na}^{+}+\mathrm{K}^{+}\right)$-ATPase (Fig. 9C). Immunoelectron microscopic examination of optic nerve also showed abundant and diffuse intracellular staining of fibrous astrocytes in the parenchyma as well as those closely appled to capillaries (Fig. 10). Heavily labeled astrocytic processes were also observed in the extracellular space overlying the node of Ranvier (Fig. $6 E$ ). Immunoperoxidase results employing the monoclonal antibody $9 \mathrm{~B} 1$ also demonstrated heavy intracellular staining in fibrous astrocytes (Fig. 11). Monoclonal antibody $9 \mathrm{~A} 5$ had a similar pattern of immunoreactivity but required higher concentrations (data not shown). The results observed with these monoclonal antibodies were similar to that obtained with the polyclonal antibody preparations. More detailed localization of the intracellular site $\left(\mathrm{Na}^{+}+\mathrm{K}^{+}\right)$-ATPase concentration will require nonenzymatic labels (such studies utilizing ferritin- and colloidal goldconjugated antibodies are in progress).

Experiments in the cerebellum of rats and mice showed $\left(\mathrm{Na}^{+}+\right.$ $\mathrm{K}^{+}$)-ATPase-like immunoreactivity in thin or velate processes of glial cells in the granule cell layer (Fig. 12A). Immunoelectron microscopy demonstrated abundant intracellular reaction product within these velate processes (Fig. 12B). These processes are characteristic of protoplasmic astrocytes as visualized with high voltage electron microscopy in Golgi-stained preparations (Palay and Chan-Palay, 1974). To determine whether these processes arose from astroglia, we examined them after reaction with anti-GFAP antibodies. These velate processes were GFAP immunoreactive, verifying that they were astrocyte processes (Fig. 12C). Other investigators have also reported $\left(\mathrm{Na}^{+}+\mathrm{K}^{+}\right)$-ATPase in astroglia. $\left(\mathrm{Na}^{+}+\mathrm{K}^{+}\right)$-ATPase immunoreactivity in the plasmalemma of pericapillary and periterminal astrocytic processes has been reported previously by Wood et al. (1977). The enzyme has also been detected in the plasmalemma of Muller cells in guinea pig retina by cytochemistry (Ueno et al., 1981). However, Broderson et al. (1978), Inomata et al. (1983), and Nasu (1983) have reported an absence of the enzyme in glial cells using cytochemical techniques.

Some glial cells in rat optic nerve were observed that were not
$\left(\mathrm{Na}^{+}+\mathrm{K}^{+}\right)$-ATPase immunoreactive (Fig. 13A). Although they were not stained with uranyl or lead salts, these cells could be identified as oligodendrocytes. They could be distinguished from astrocytes, based on their characteristic morphology (Peters et al., 1976). They exhibited dense and eccentric nuclei, dark cytoplasm, a well developed rough endoplasmic reticulum, and few cytoplasmic fibrils or glycogen granules (Fig. 13B). Thus, it appears that oligodendrocytes in the rat optic nerve have little intracellular or plasmalemmal $\left(\mathrm{Na}^{+}+\right.$ $\mathrm{K}^{+}$)-ATPase-like immunoreactivity. Labeling along the outer myelin sheath of oligodendrocytes was not noteworthy (Fig. $6 E)$. $\left(\mathrm{Na}^{+}+\right.$ $\mathrm{K}^{+}$)-ATPase immunoreactivity has been reported by others in association with the somal plasmalemma of oligodendroglia (Wood et al., 1977 ) and on their outer myelin sheath (Wood et al., 1977; Schwartz et al., 1981).

In contrast to the results observed in oligodendrocytes, the myelinating cell type of the PNS, the Schwann cell, showed plasmalemmal $\left(\mathrm{Na}^{+}+\mathrm{K}^{+}\right)$-ATPase immunoreactivity. Immunofluorescence experiments on teased spinal roots from rats with polyclonal antibodies demonstrated continuous $\left(\mathrm{Na}^{+}+\mathrm{K}^{+}\right)$-ATPase immunoreactivity along the outer loops of the Schwann cell process (Fig. 6B). Monoclonal antibodies 9A5 and 9B1 (Fig. 14) also demonstrated similar results in teased single fibers from the spinal root of rats. Immunoelectron microscopy of mouse spinal root showed staining of the terminal loops overlying the nodal axolemma (Fig. 6G). These results were not surprising since the Schwann cell, unlike the oligodendrocyte, has a cytoplasm-filled terminal wrapping of the myelin sheath. Cytochemical examination of $\left(\mathrm{Na}^{+}+\mathrm{K}^{+}\right)$-ATPase in peripheral nerves of mice showed an absence of the enzyme in the microvilli of Schwann cells overlying the node of Ranvier (Vorbrodt et al., 1982).

Epithelial cells of the choroid plexus. Epithelial cells of the choroid plexus from the fourth ventricle of rats had positive $\left(\mathrm{Na}^{+}+\mathrm{K}^{+}\right)$ATPase immunoreactivity exclusively along the apical surface of the cell. Absorbed controls did not demonstrate significant immunoreactivity (Fig. 15). Similar results have also been reported employing autoradiography (Quinton et al., 1973) and immunocytochemistry 


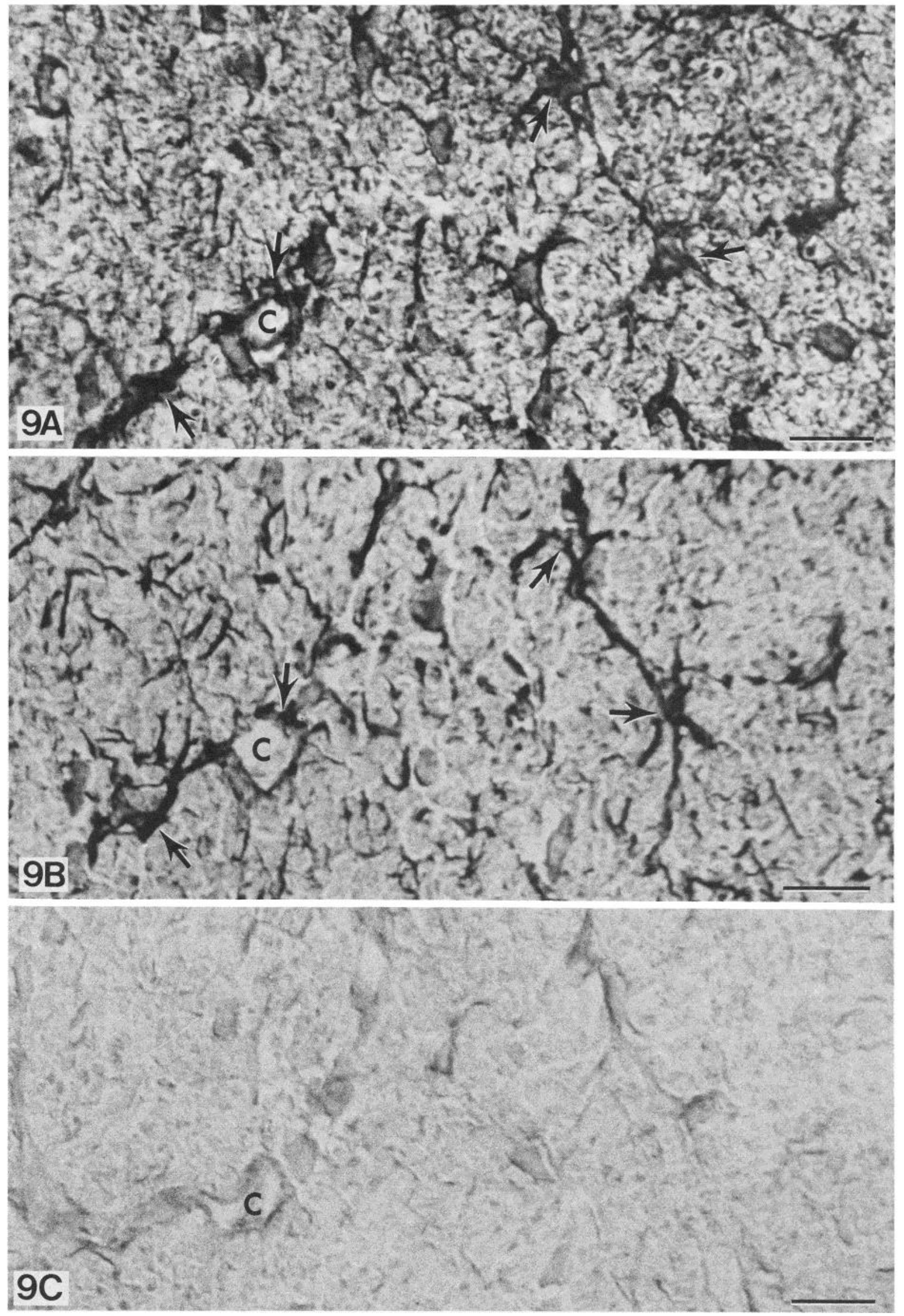

Figure 9. Immunoperoxidase experiment on serial sections of rat optic nerve, dernonstrating $\left(\mathrm{Na}^{+}+\mathrm{K}^{+}\right)$-ATPase and GFAP immunoreactivity co-localized in the same cells. $A,\left(\mathrm{Na}^{+}+\mathrm{K}^{+}\right)$-ATPase-like immunoreactivity in glial cells. Note the positive labeling (arrows) of the somas and processes around capillaries (c). B, GFAP-immunoreactive cells in a serial section (arrows). These cells were astrocytes. C, Preabsorbed controls had little $\left(\mathrm{Na}^{+}+\mathrm{K}^{+}\right)$-ATPase-like immunoreactivity. (Normal rabbit serum controls appeared similar. The contribution of peroxidase-containing granules (Kumamoto, 1981) to staining in the experimental preparations was negligible (data not shown.)) Nomarski differential interference contrast optics. Bar $=2 \mu \mathrm{m}$. 

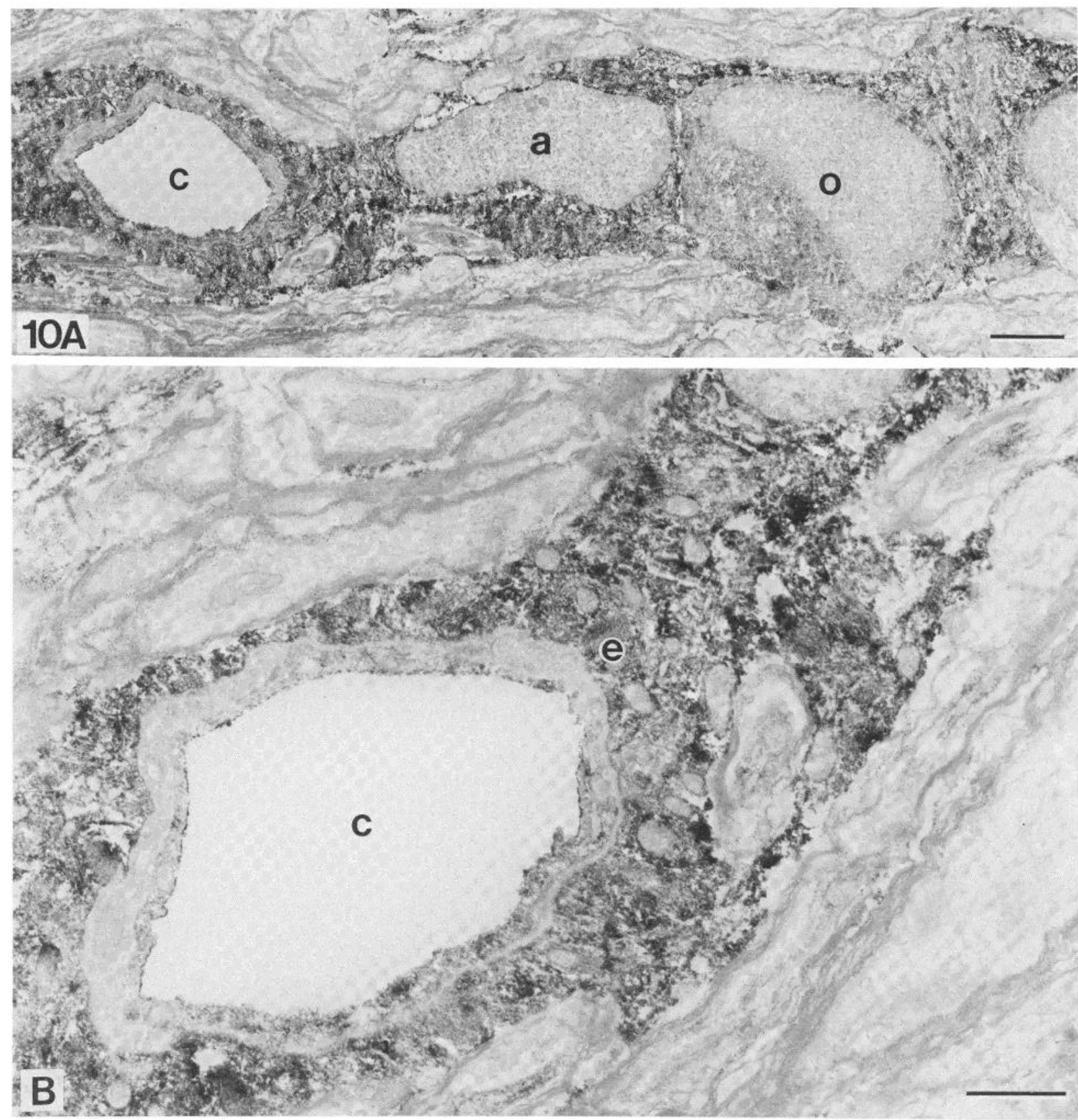

Figure 10. Immunoelectron microscopy of fibrous astrocytes from a longitudinal section of rat optic nerve. Note the abundant intracellular staining. $A$, Lower magnification of processes extending from an astrocyte $(a)$, heavily stained for $\left(\mathrm{Na}^{+}+\mathrm{K}^{+}\right)$-ATPase and surrounding a capillary $(c)$, and an oligodendrocyte (o). Bar $=2 \mu \mathrm{m}$. B, A higher magnification of the pericapillary astrocytic process in $A$. End-feet of the process $(e)$ were also heavily stained. $B a r=1 \mu \mathrm{m}$.

(Masuzawa et al., 1984; Siegel et al., 1984). Cytochemical techniques have reported $\left(\mathrm{Na}^{+}+\mathrm{K}^{+}\right)$-ATPase in both regions. Milhorat et al. (1975) concluded that $\left(\mathrm{Na}^{+}+\mathrm{K}^{+}\right)$-ATPase was confined to the basolateral plasmalemma of choroid epithelial cells based on their results. Other investigators (Masuzawa et al., 1981) have reported $\left(\mathrm{Na}^{+}+\mathrm{K}^{+}\right)$ATPase in the microvillar processes and basal, but not lateral, plasmalemma of choroid plexus cells using cytochemical methods.

\section{Discussion}

This paper describes the development and characterization of polyclonal antibodies to rat $\left(\mathrm{Na}^{+}+\mathrm{K}^{+}\right)$-ATPase. These antibodies cross-react in varying amounts with dog and eel $\left(\mathrm{Na}^{+}+\mathrm{K}^{+}\right)$-ATPase.
These probes, along with the anticatalytic monoclonal antibody preparations (previously characterized by Schenk and Leffert, 1983, and Schenk et al., 1984) raised against rat renal $\left(\mathrm{Na}^{+}+\mathrm{K}^{+}\right)$-ATPase have demonstrated immunocytochemically that they bind to $\left(\mathrm{Na}^{+}+\right.$ $\mathrm{K}^{+}$)-ATPase in rat nervous tissue. The results with these different probes were similar, showing regions of focal concentration of the enzyme. $\left(\mathrm{Na}^{+}+\mathrm{K}^{+}\right)$-ATPase-like immunoreactivity was observed along the plasmalemma of neurons and at the nodal, but not the paranodal or internodal, axolemma of myelinated axons of the CNS and PNS. Astroglia had abundant plasmalemmal and intracellular $\left(\mathrm{Na}^{+}+\mathrm{K}^{+}\right)$-ATPase-like immunoreactivity. The plasmalemma of Schwann cells were positively labeled, particularly in the paranodal region. The soma and myelin of oligodendroglia were not positively stained for the enzyme. 
Interspecies and isozyme cross-reactivity. Results obtained with ELISAs demonstrate that there is limited cross-reactivity between polyclonal antibodies raised against $\left(\mathrm{Na}^{+}+\mathrm{K}^{+}\right)$-ATPase from one species for the enzyme from another species. These data suggest that even in mammals as closely related as the dog and rat there are variabilities in enzyme structure. This suggests that results from xenogenic immunocytochemical studies must be interpreted with caution. In this study, a careful comparison between rats and mice showed no qualitative differences in the distribution of $\left(\mathrm{Na}^{+}+\mathrm{K}^{+}\right)$ATPase in neurons and glia. This suggests a high degree of crossreactivity between these anti-rat $\left(\mathrm{Na}^{+}+\mathrm{K}^{+}\right)$-ATPase antibodies and the mouse enzyme, allowing these probes to be used in the future in various mutant mouse models.

The immunocytochemical data suggest that both the polyclonal and monoclonal preparations recognize isozymes of $\left(\mathrm{Na}^{+}+\mathrm{K}^{+}\right)$ATPase found in the nervous system (Sweadner, 1979; Urayama and Nakao, 1979; Rubin et al., 1981). Sweadner (1979) has reported two principal forms of the higher molecular weight subunit of the enzyme, referred to as $\alpha$ and $\alpha+$, in the brains of a number of species. Only the $\alpha+$ form appears to be present in axolemmal tissue fractions from myelinated axons from the CNS (excluding synaptosomal fractions), even though some neurons apparently synthesize both forms (Specht and Sweadner, 1984). Glial cells were found to contain only the $\alpha$-subunit which appeared very similar to the form found in kidney. In this study, polyclonal antibody preparations required higher concentrations to detect the axolemmal form of the enzyme. One interpretation of these data suggest that only a subset of the polyclonal antibodies raised against the glial/renal form cross-reacts with high affinity for the axolemmal form of the enzyme. Previous reports have also demonstrated cross-reactivity between antibody preparations raised against non-nervous system $\left(\mathrm{Na}^{+}+\right.$ $\mathrm{K}^{+}$)-ATPase and brain enzyme in the same species (McCans et al., 1975; Jean and Albers, 1976; see Note added in proof).
Distribution of $\left(\mathrm{Na}^{+}+\mathrm{K}^{+}\right)$-ATPase along myelinated axons. The presence or absence of $\left(\mathrm{Na}^{+}+\mathrm{K}^{+}\right)$-ATPase in the paranodal and internodal axolemma is currently an unresolved question. Based on our present concept of nerve impulse conduction along myelinated neurons, the ionic fluxes associated with propagation of the action potential occur in the region of the nodal membranes. The paranodal and internodal membrane are presumably not involved either because they are covered by myelin or because they lack the necessary membrane macromolecules, specifically sodium channels and $\left(\mathrm{Na}^{+}+\mathrm{K}^{+}\right)$-ATPase. We recently determined by immunoelectromicroscopy that distribution of the sodium channel was restricted to the nodal axolemma in the absence of myelin barriers to immunocytochemical reagents (Ellisman and Levinson, 1982; Ellisman et al., 1983).

Although early immunocytochemical reports did not detect $\left(\mathrm{Na}^{+}\right.$ $+\mathrm{K}^{+}$)-ATPase in the internodal or paranodal axolemma (Wood et al., 1977; Schwartz et al., 1981), these studies could not conclude that the enzyme was absent in these regions because of the possibility of limited accessibility of the immunocytochemical reagents with the techniques employed. Cytochemical examinations in mouse (Vorbrodt et al., 1982) and rat (Inomata et al., 1983; Nasu, 1983) have shown $\left(\mathrm{Na}^{+}+\mathrm{K}^{+}\right)$-ATPase in the axolemma of myelinated fibers. However, the ability to detect specific $\left(\mathrm{Na}^{+}+\mathrm{K}^{+}\right)$ATPase activity using these techniques requires that all other $\mathrm{P}_{\mathrm{i}}$ liberating reactions are blocked. On occasion, the distribution of $\left(\mathrm{Na}^{+}+\mathrm{K}^{+}\right)$-ATPase reported using this technique has differed markedly from reports employing other methods (see discussion below). An immunocytochemical investigation in chicken also showed the enzyme in the internodal and paranodal axolemma (Fambrough and Bayne, 1983). Although not our primary purpose, we would like to offer a different interpretation of these results based on the following observations (Fambrough and Bayne, 1983; refer to Fig. 10). The use of unfixed, noncryoprotected frozen tissue raises

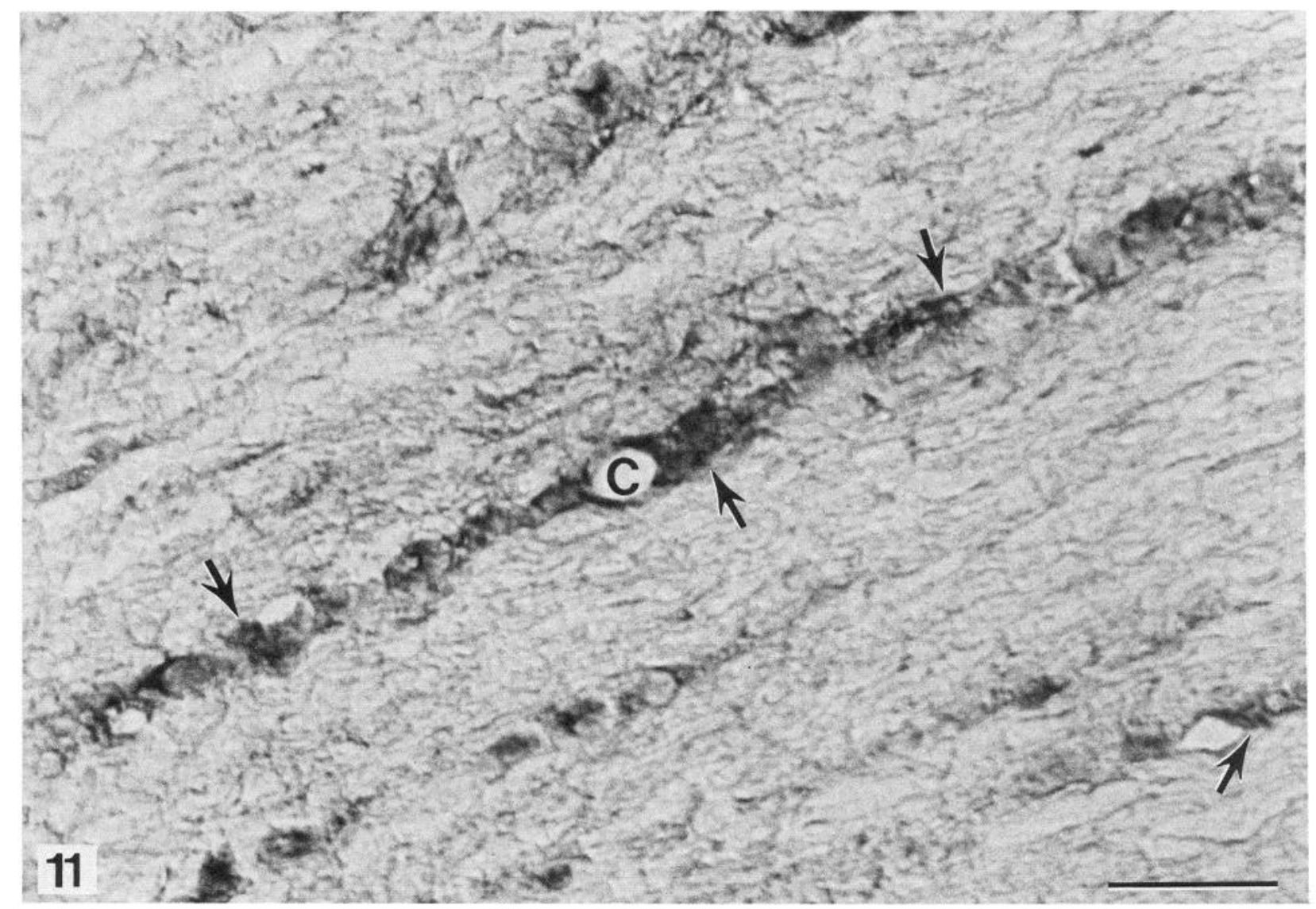

Figure 11. Immunoperoxidase results in longitudinal sections of rat optic nerve employing monoclonal antibody 9B1. Heavy intracellular staining was present in the processes of glial cells (arrows), including those around capillaries (C). Nomarski differential interference contrast optics. Bar $=15 \mu \mathrm{m}$. 

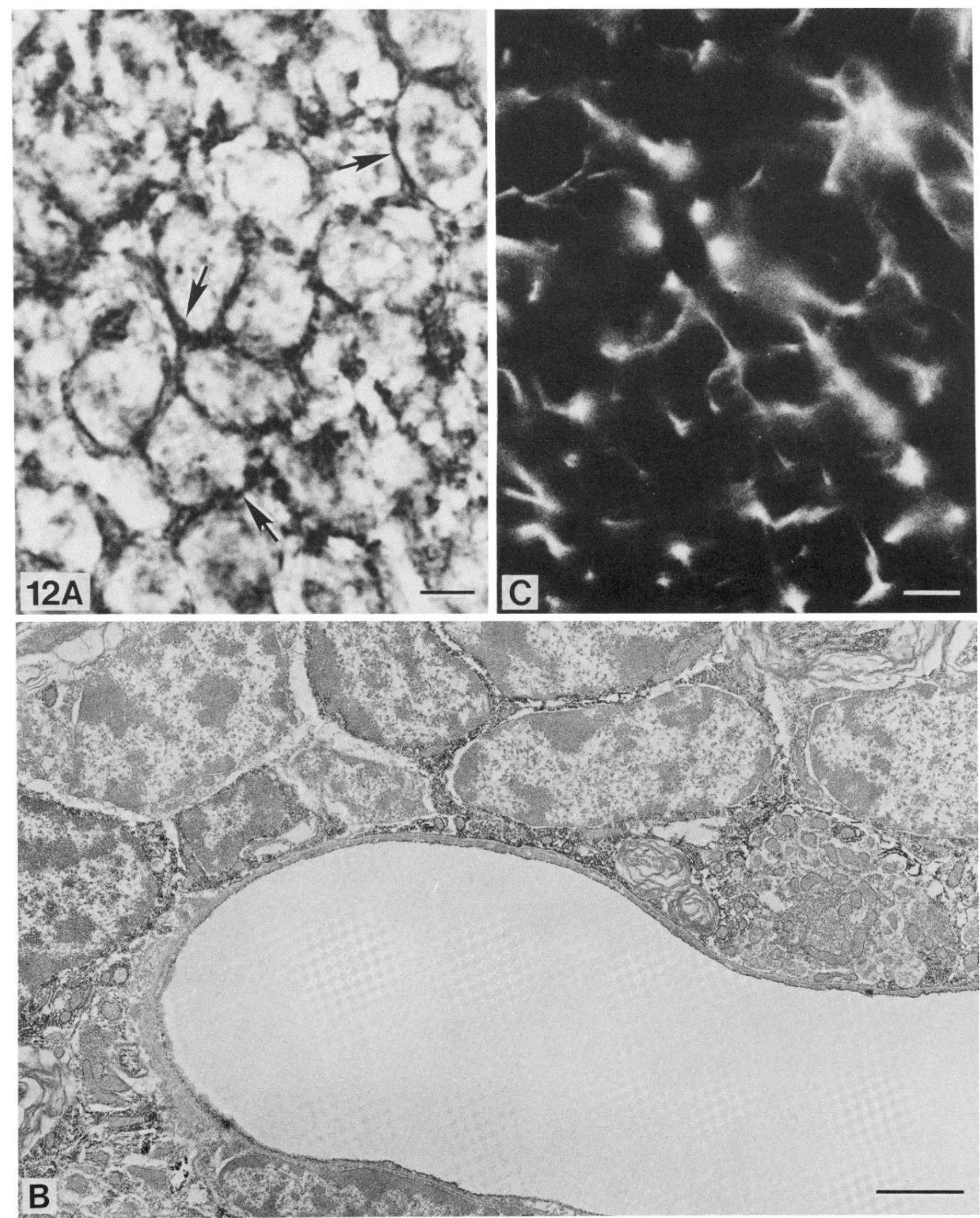

Figure 12. $\left(\mathrm{Na}^{+}+\mathrm{K}^{+}\right)$-ATPase immunoreactivity in the cerebellum of rats and mice. A, Phase contrast image of immunoperoxidase results of experiments employing anti-( $\left.\mathrm{Na}^{+}+\mathrm{K}^{+}\right)$-ATPase antibodies in mouse cerebellum. Note cytoplasmic immunoreactivity in the delicate cellular processes $($arrows $)$. Bar $=3$ $\mu \mathrm{m}$. $B$, Electron microscopic localization of $\left(\mathrm{Na}^{+}+\mathrm{K}^{+}\right)$-ATPase in the granule cell layer of the rat cerebellum. Bar $=2 \mu \mathrm{m}$. C, Anti-GFAP immunofluorescence was also observed in these delicate processes identifying them as velate processes of astrocytes. $B a r=6 \mu \mathrm{m}$. 

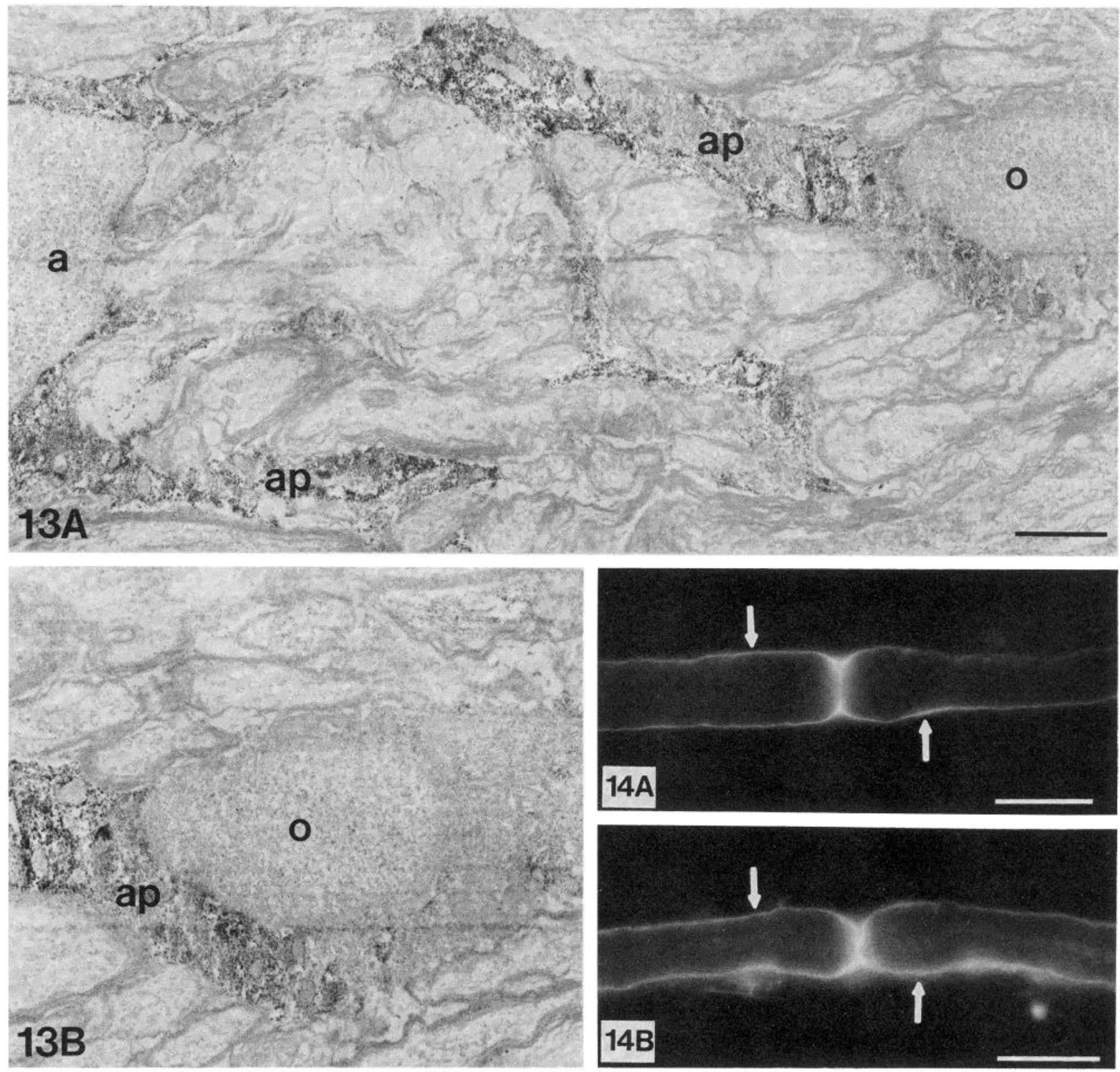

Figure 13. Some glial cells in rat optic nerve were not $\left(\mathrm{Na}^{+}+\mathrm{K}^{+}\right)$-ATPase immunoreactive. $A$, One example (o) can be identified as an oligodendrocyte based on morphologic criteria and can be distinguished from astrocytes $(a)$ and astrocyte processes (ap) which were $\left(\mathrm{Na}^{+}+\mathrm{K}^{+}\right)$-ATPase immunoreactive. $B a r=2 \mu \mathrm{m}$. B. Higher magnification of the oligodendrocyte in $A$. Bar $=1 \mu \mathrm{m}$.

Figure 14. $\left(\mathrm{Na}^{+}+\mathrm{K}^{+}\right)$-ATPase immunoreactivity along the Schwann cell plasmalemma using monoclonal antibody preparation. Antibodies $9 \mathrm{A5}(A)$ and 9B1 (B) positively labeled the outer loop of Schwann cells of myelinated axons from rat spinal root (arrows). Bar $=20 \mu \mathrm{m}$.

the question of membrane integrity. The absence of well preserved morphological structures makes it difficult to distinguish between axolemmal and other membranes. Also, it is possible that, in the absence of reported controls, nonspecific interaction in the internodal region could account for the observed immunoreactivity. The use of a monoclonal antibody did not eliminate the possibility of cross-reactivity with other proteins (for example, see Lindstrom et al., 1979, p. 4475), although availability of an anticatalytic monoclonal antibody would have suggested an additional level of specificity. Thus, localization studies done previously have not resolved the question of whether or not $\left(\mathrm{Na}^{+}+\mathrm{K}^{+}\right)$-ATPase is concentrated in the internodal and paranodal axolemma.

Our report addressed this controversy directly. The data presented show that the level of the enzyme was undetectable in the internodal and paranodal regions while being readily detectable at the nodal axolemma in the absence of permeability barriers to immunocyto- chemical reagents. It would be inappropriate to claim that $\left(\mathrm{Na}^{+}+\right.$ $\mathrm{K}^{+}$)-ATPase was not present in the internodal axolemma because the technique employed might not be sensitive enough to detect small concentrations of the enzyme on the order necessary to compensate for passive leakage of $\mathrm{Na}$ and $\mathrm{K}$ ions through the axolemma. The data do demonstrate significant differences in the levels of $\left(\mathrm{Na}^{+}+\mathrm{K}^{+}\right)$-ATPase-like immunoreactivity in the membranes of the internodal and paranodal regions of the axolemma versus the nodal axolemma itself.

The role of astroglia in ionic homeostasis. This report may contribute toward a better understanding of the relative roles of neuron and glia in maintaining ionic homeostasis in nervous tissue. Early investigations suggested that increased extracellular $\mathrm{K}$ was dissipated by diffusion through the extracellular space (reviewed by Kuffler, 1967). Later work suggested that glial cells were passively involved in the uptake of elevated extracellular K (reviewed by Varon 

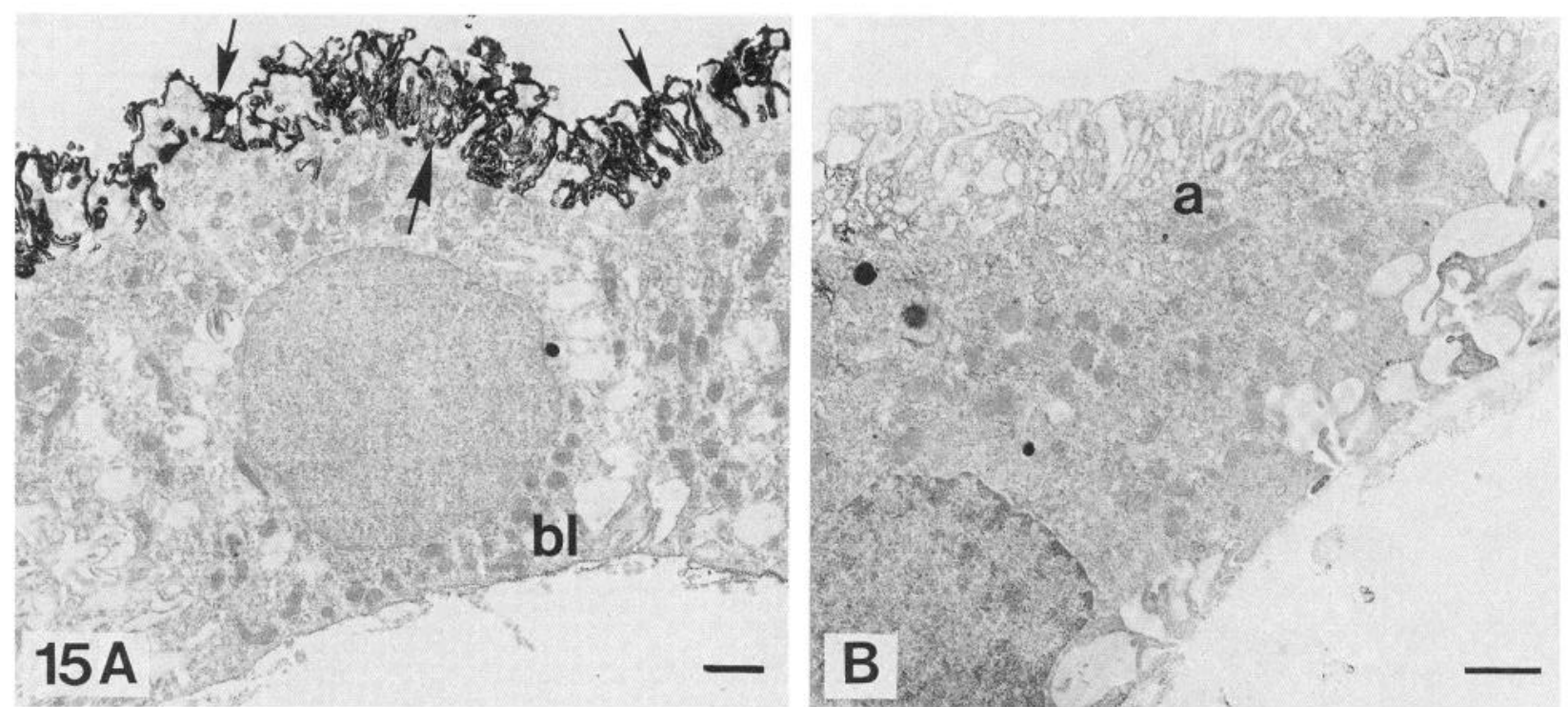

Figure 15. $\left(\mathrm{Na}^{+}+\mathrm{K}^{+}\right)$-ATPase in epithelial cells of the choroid plexus. $A$, experimental preparations showed that deposition of the reaction product (arrows) was present only along the apical membrane and not along the basolateral membrane $(b /)$. $B$, Absorbed control preparations showed little $\left(\mathrm{Na}^{+}+\right.$ $\mathrm{K}^{+}$)-ATPase immunoreactivity, a, apical membrane. Bar $=1 \mu \mathrm{m}$.

and Somjen, 1979). However the ability of $\left(\mathrm{Na}^{+}+\mathrm{K}^{+}\right)$-ATPase to catalyze the antiport of $\mathrm{Na}$ and $\mathrm{K}$ ions across cell membranes suggested that it might play a significant role in the reabsorbtion of $\mathrm{K}$ ions by astrocytes. Studies have described $\left(\mathrm{Na}^{+}+\mathrm{K}^{+}\right)$-ATPase in astrocytes and the ability of this enzyme in cell cultures of astrocytes to contribute to the uptake of elevated concentrations of $\mathrm{K}$ ions (Walz and Hertz, 1982). Early immunocytochemical work in Sternarchus (Wood et al., 1977) demonstrated the enzyme in astrocyte processes surrounding capillaries and terminals supporting this concept. In a more recent study on mouse brain at the light level employing immunocytochemical techniques, Siegel et al. (1984) were unable to determine whether staining in some regions was attributable to neurons or glia. Data generated using cytochemical methods to determine the location of $\left(\mathrm{Na}^{+}+\mathrm{K}^{+}\right)$-ATPase in rats are conflicting. Using this technique, enzyme activity was detected along dendritic plasmalemma but not in association with glial membranes (Stahl and Broderson, 1976; Broderson et al., 1978; Inomata et al., 1983; Nasu, 1983). These results might be interpreted to suggest that neurons, not glia, are the primary cell type involved in maintaining extracellular $\mathrm{K}$ ion homeostasis. These inconsistencies between reports on the relative distribution of $\left(\mathrm{Na}^{+}+\mathrm{K}^{+}\right)$-ATPase in glial and neuronal cells may be attributable to differences in the techniques employed.

In the present work we addressed this question by re-examining the distribution of $\left(\mathrm{Na}^{+}+\mathrm{K}^{+}\right)$-ATPase in neurons and astrocytes in rats and mice using immunocytochemical techniques. The enzyme was detected in the somal plasmalemma and nodal axolemma of neurons. Abundant amounts of $\left(\mathrm{Na}^{+}+\mathrm{K}^{+}\right)$-ATPase-like immunoreactivity was also observed in association with the plasmalemma of the soma and distal processes of astrocytes. The cytoplasm also contained reaction product, suggesting large amounts of the enzyme within these cells, possibly in association with a cytoplasmic membrane system. Some of this immunoreactivity could represent proenzymatic forms of $\left(\mathrm{Na}^{+}+\mathrm{K}^{+}\right)$-ATPase. The possibility also remains that the polyclonal antibodies, and even the anticatalytic monoclonal antibodies, are cross-reacting with another antigen, perhaps an ionbinding protein. Astrocytic processes forming pericapillary end-feet demonstrated considerable labeling similar to results reported in Stenarchus. In addition, we noted that astrocytic processes overlying the node of Ranvier also exhibited abundant $\left(\mathrm{Na}^{+}+\mathrm{K}^{+}\right)$-ATPaselike immunoreactivity. This may be particularly important considering the small volume of the perinodal cuff of extracellular fluid where rapid, and frequently repeated ionic or fluid flux would significantly alter ionic concentrations, in particular local sodium and potassium ion gradients. This is particularly interesting since $\left(\mathrm{Na}^{+}+\mathrm{K}^{+}\right)$ATPase-like immunoreactivity was not detected on the plasmalemma or outer myelin sheath of oligodendrocytes. These data provide additional, new evidence implicating astrocytes in the maintenance of a homeostatic environment in regions of large ionic flux. A functionally equivalent role may be performed by Schwann cells in the PNS. Our observations of $\left(\mathrm{Na}^{+}+\mathrm{K}^{+}\right)$-ATPase-like immunoreactivity in the terminal loops and microvillar processes overlying the node of Ranvier suggest a similar role for Schwann cells in the homeostasis of the extracellular fluid in this region. It is interesting to note along these lines that an abnormality in glial $\left(\mathrm{Na}^{+}+\mathrm{K}^{+}\right)$-ATPase has been established in epileptogenic tissue (reviewed by Grisar, 1984).

Comparison of the different techniques. Cytochemical techniques and immunocytochemical methods for localizing $\left(\mathrm{Na}^{+}+\mathrm{K}^{+}\right)$-ATPase have, on occasion, given different results when compared. As an example, differences in detecting $\left(\mathrm{Na}^{+}+\mathrm{K}^{+}\right)$-ATPase in astrocytes have already been noted. Another example is the epithelial cells of the choroid plexus (see "Results"). The reasons for such a disparity have not been determined. These discrepancies may arise because the immunocytochemical technique requires conservation of enzyme conformation, while the cytochemical method further necessitates preservation of enzymatic activity. Mayahara and Ogawa (1980) have reported in a detailed study in rat kidney that, under their experimental conditions, $45 \%$ of the enzymatic activity remains. The immunocytochemical technique may offer greater sensitivity although it could detect nonenzymatically active forms of the antigen.

Some differences have been noted when comparing results of the distribution of $\left(\mathrm{Na}^{+}+\mathrm{K}^{+}\right)$-ATPase from this study with data from other reports using a variety of techniques. However, our polyclonal results did agree where staining has been reported (at the node of Ranvier and plasmalemma) using all of these techniques. Polyclonal and monoclonal data agreed with other immunocytochemical results reported in astrocytes. Thus, the biochemical and immunocytochemical resuts demonstrate that these monoclonal and polyclonal antibodies are highly specific for $\left(\mathrm{Na}^{+}+\mathrm{K}^{+}\right)$-ATPase and that the observations reported have been achieved with accurate probes for the enzyme.

Note added in proof. Additional data supporting this interpretation was acquired recently in collaboration with $\mathrm{Dr}$. A. McDonough. It 
was determined that the polyclonal antibodies described in this report bind primarily to the $\alpha$ form and less to the $\alpha+$ form in immunoblot of the enzyme from brain. In contrast, polyclonal antibodies raised to the enzyme from guinea pig kidney (McDonough, 1985 ) react most strongly with $\alpha+$ form from rat brain. When these "anti $\alpha+$ " antibodies were used to probe the enzyme's distribution in peripheral nerve, staining of the Schwann cell plasmalemma was absent. The axolemma of the nodal membrane, however, stained heavily. This indicates that the $\left(\mathrm{Na}^{+}+\mathrm{K}^{+}\right)$-ATPase of the nodal membrane is principally of the $\alpha+$ variety while that of the Schwann cell plasmalemma is of the $\alpha$ form.

\section{References}

Ariyasu, R. G., M. H. Ellisman, J. ^. Nichol, and T. J. Deerinck (1982) Immunocytochemical localization of sodium-potassium adenosine triphosphatase in the rat central nervous system. Soc. Neurosci. Abstr. 8: 415.

Bonting, S. J. (1970) Sodium-potassium activated adenosine triphosphatase and cation transport. In Membranes and Ion Transport, E. E. Bittar, ed. pp. 258-363, Wiley-Interscience, London.

Broderson, S. H., U.L. Patton, and W. L. Stahl (19/8) rine structural localization of potassium-stimulated $p$-nitrophenylphosphatase activity in dendrites of the cerebral cortex. J. Cell Biol. 77: R13-R17.

Burnette, W. N. (1981) "Western Blotting": Electrophoretic transfer of proteins from sodium dodecyl sulphate-polyacrylamide gels to unmodified nitrocellulose and radiographic detection with antibody and radioiodinated protein A. Anal. Biochem. 112: 195-203.

Craig, W. S., and J. Kyte (1980) Stoichiometry and molecular weight of the minimum asymmetric unit of canine renal sodium and potassium ionactivated adenosine triphosphatase. J. Biol. Chem. 225: 6262-6269.

DiBona, D. R., and J. W. Mills (1979) Distribution of $\mathrm{Na}^{+}$-pump sites in transporting epithelia. Fed. Proc. 38: 134-143.

Dixon, J. F., and L. E. Hokin (1978) A simple procedure for one preparation of highly purified (sodium and potassium) adenosine triphosphatase from the rectal salt gland of Squalus acanthias and the electric organ of Electrophorus electricus. Anal. Biochem. 86: 378-385.

Ellisman, M. H., and S. R. Levinson (1982) Immunocytochemical localization of sodium channel distribution in the excitable membrane of Electrophorus electricus. Proc. Natl. Acad. Sci. U. S. A. 79: 6707-6711.

Ellisman, M. H., J. D. Lindsey, C. A. Wiley-Livingston, and S. R. Levinson (1983) Differentiation and maintenance of the membrane cytoskeletal structure in nerve. In Structure and Function in Excitable Cells, D. C. Chang, I. Tasaki, W. J. Adelman, Jr., and H. R. Leuchtag, eds., pp. 3-23. Plenum Publ. Corp., New York.

Eng, L. F., and S. J. DeArmond (1981) Glial fibrillary acidic (GFA) protein immunocytochemistry in development and neuropathology. Prog. Clin. Biol. Res. 59A: 65-79.

Eng, L. F., J. J. Vanderhaeghen, A. Bignami, and B. Gerstl (1971) An acidic protein isolated from fibrous astrocytes. Brain Res. 28: 351-354.

Engvall, E., and P. Perlmann (1972) Enzyme-linked immunosorbent assay, ELISA. III. Quantitation of specific antibodies by enzyme-labelled antiimmunoglobulin in antigen-coated tubes. J. Immunol. 109: 129-135.

Ernst, S. A., and J. W. Mills (1980) Autoradiographic localization of tritiated ouabain-sensitive sodium pump sites in ion transporting epithelia. J. Histochem. Cytochem. 28: 72-77.

Fambrough, D. M., and E.K. Bayne (1983) Multiple forms of $\left(\mathrm{Na}^{+}+\mathrm{K}^{+}\right)$ATPase in the chicken. J. Biol. Chem. 258: 3926-3935

Grisar, T. (1984) Glial and neuronal $\mathrm{Na}^{+} \mathrm{K}^{+}$pump in epilepsy. Ann. Neurol. 16 (Suppl); S128-134.

Henn, F. A., H. Haljamae, and A. Hamberger (1972) Glial cell function: Active control of extracellular $\mathrm{K}^{+}$concentration. Brain Res. 43: 437-443.

Hopkins, B. E., H. Wagner, Jr., and T. W. Smith (1976) Sodium- and potassium-activated adenosine triphosphatase of the nasal salt gland of the duck (Anas platyrhynchos). J. Biol. Chem. 251: 4365-4371.

Inomata, K., H. Mayahara, K. Fujimoto, and K. Ogawa (1983) Ultrastructural localization of ouabain-sensitive potassium-dependent $p$-nitrophenylphosphatase $\left(\mathrm{Na}^{+}-\mathrm{K}^{+}\right.$-ATPase) activity in the central nervous system of the rat. Acta Histochem. Cytochem. 16: 277-285.

Jean, D. H., and R. W. Albers (1976) immunochemical studies on the large polypeptide of Electrophorus electroplax $\left(\mathrm{Na}^{+}+\mathrm{K}^{+}\right)$-ATPase. Biochim. Biophys. Acta 452: 219-226.

Jorgensen, P. L. (1974) Purification and characterization of $\left(\mathrm{Na}^{+}+\mathrm{K}^{+}\right)$ATPase. III. Purification from the outer medulla of mammalian kidney after sclcctive rcmoval of membrane components by sodium dodecyl sulphate. Biochim. Biophys. Acta 356: 36-52.
Jorgensen, P. L. (1982) Mechanism of the $\mathrm{Na}^{+}, \mathrm{K}^{+}$pump. Protein structure and conformations of the pure $\left(\mathrm{Na}^{+} \mathrm{K}^{+}\right)$-ATPase. Biochim. Biophys. Acta 694: $27-68$

Jorgensen, P. L., and J. C. Skou (1969) Preparation of highly active $\left(\mathrm{Na}^{+}+\mathrm{K}^{+}\right)$ ATPase from the outer medulla of rabbit kidney. Biochem. Biophys. Res. Commun. 37: 39-46.

Kuffler, S. W. (1967) Neuroglial cells: Physiological properties and a potassium mediated effect of neuronal activity on the glial membrane potential. Proc. R. Soc. Lond. (Biol.) 168: 1-19.

Kumamoto, T. (1981) Histochemical study on endogenous diaminobenzidinepositive granules in the glia cell of rat brain. Acta Histochem. Cytochem. 14: 173-185.

Kyte, $\mathrm{J}$. (1971) Purification of the potassium- and potassium-dependent adenosine triphosphatase from canine renal medulla. J. Biol. Chem. 246 : 4157-4165.

Kytc, J. (1972) Propertics of the two polypeptides of sodium- and potassiumdependent adenosine triphosphatase. J. Biol. Chem. 247: 7642-7649.

Kyte, J. (1976a) Immunoferritin determination of the distribution of $\left(\mathrm{Na}^{+}+\right.$ $\left.\mathrm{K}^{+}\right)$ATPase over the plasma mernbranes of renal convoluted tubules. I. Distal segment. J. Cell Biol. 68: 287-303.

Kyte, J. (1976b) Immunoferritin determination of the distribution of $\left(\mathrm{Na}^{+}+\right.$ $\mathrm{K}^{+}$) ATPase over the plasma membranes of renal convoluted tubules. II. Proximal segment. J. Cell Biol. 68: 304-318.

Laemmli, U. K. (1970) Cleavage of structural proteins during the assembly of the head of bacteriophage T4. Nature 227: $680-685$.

Lindstrom, J., B. Walter (Nave), and B. Einarson (1979) Immunochemical similarities between subunits of acetylcholine receptors from Torpedo, Electrophorus, and mammalian muscle. Biochemistry 18: 4470-4480.

Louvard, D. (1980) Apical membrane aminopeptidase appears at the site of cell-cell contact in cultured kidney epithelial cells. Proc. Natl. Acad. Sci. U. S. A. 77: 4132-4136.

Lowry, O. H., N. J. Rosebrough, A. L. Farr, and R. J. Randall (1951) Protein measurement with the Folin reagent. J. Biol. Chem. 193: 265-267.

Masuzawa, T., T. Ohta, M. Kawamura, N. Nakahara, and F. Sato (1984) Immunohistochemical localization of $\mathrm{Na}^{+}, \mathrm{K}^{+}$-ATPase in the choroid plexus. Brain Res. 302: 357-362.

Masuzawa, T., T. Saito, and F. Sato (1981) Cytochemical study on enzyme activity associated with cerebrospinal fluid secretion in the choroid plexus and ventricular ependyma. Brain Res. 222: 309-322.

Mayahara, H., and K. Ogawa (1980) Ultracytochemical localization of ouabain-sensitive, potassium-dependent $p$-nitrophenylphosphatase activity in the rat kidney. Acta Histochem. Cytochem. 13: 90-102.

McCans, J. L., G. E. Lindenmayer, B. J. R. Pitts, M. V. Ray, B. D. Raynor, V. P. Butlyer, and A. Schwartz (1975) Antigenic differences in $\left(\mathrm{Na}^{+}, \mathrm{K}^{+}\right)$ATPase preparations isolated from various organs and species. J. Biol. Chem. 250: 7257-7265.

McDonough, A. (1985) Immuno detection of Na,K.ATPase in guinea-pig retinal layers cornea and lens. Exp. Eye Res. 40: 667-674.

McLean, I. W., and P. K. Nakane (1974) Periodate-lysine-paraformaldehyde fixative. A new fixative for immunoelectron microscopy. J. Histochem. Cytochem. 22: 1077-1083.

Milhorat, T. H., D. A. Davis, and M.K. Hammock (1975) Localization of ouabain-sensitive Na-K-ATPase in frog, rabbit and rat choroid plexus. Brain Res. 99: 170-174.

Morrissey, J. H. (1981) Silver stain for proteins in polyacrylamide gels: A modified procedure with enhanced uniform sensitivity. Anal. Biochem. 117: $307-310$

Nasu, F. (1983) Ultracytochemical demonstration of ouabain-sensitive, $\mathrm{K}^{+}$ dependent $\mathrm{p}$-nitro-phenylphosphatase $\left(\mathrm{Na}^{+}+\mathrm{K}^{+}\right.$ATPase) activity in the rat hippocampal formation. Acta Histochem. Cytochem. 16: 368-373.

Palay, S. L., and V. Chan-Palay (1974) Cerebellar Cortex Cytology and Organization, Springer-Verlag, Berlin.

Peters, A., S. L. Palay, and H. deF. Webster (1976) The Fine Structure of the Nervous System: The Neurons and Supporting Cells, pp. 231-263, W. B. Saunders Co., Philadelphia.

Peterson, G. L., R. D. Ewing, S. R. Hootman, and F. P. Conte (1978) Large scale partial purification and molecular and kinetic properties of the $\left(\mathrm{Na}^{+}, \mathrm{K}^{+}\right)$-activated adenosine triphosphatase from Artemia salina nauplii. J. Biol. Chem. 253: 4762-4770.

Quinton, P. M., E. M. Wright, and J. M. Tormey (1973) Localization of sodium pumps in the choroid plexus epithelium. J. Cell Biol. 58: 724-730.

Rubin, R. L., A. F. Clark, and W. L. Stahl (1981) The insect brain $\left(\mathrm{Na}^{+}+\mathrm{K}^{+}\right)$ATPase binding of the ouabain in the hawk moth, Manduca sexta. Biochim. Biophys. Acta 649: 202-210.

Sanes, J. R., and Z. W. Hall (1979) Antibodies that bind specifically to synaptic sites on muscle fiber basal lamina. J. Cell Biol. 38: 347-370. 
Schenk, D. B., and H. L. Leffert (1983) Monoclonal antibodies to rat $\mathrm{Na}^{+}, \mathrm{K}^{+}-$ ATPase block enzymatic activity. Proc. Natl. Acad. Sci. U. S. A. 80:52815285.

Schenk, D. B., J. J. Hubert, and H. L. Leffert (1984) Use of a monocional antibody to quantify $\left(\mathrm{Na}^{+}+\mathrm{K}^{+}\right)$-ATPase activity and sites in normal and regenerating rat liver. J. Biol. Chem. 259: 14941-14951.

Schwartz, M., S. A. Ernst, G. J. Siegel, and B. W. Agranoff (1981) Immunocytochemical localization of $\left(\mathrm{Na}^{\prime}, \mathrm{K}^{\prime}\right)$-ATPase in the goldfish optic nerve. J. Neurochem. 36: 107-115.

Siegel, G. J., C. Holm, J. H. Schreiker, T. Desmond, and S. A. Ernst (1984) Purification of mouse brain $\left(\mathrm{Na}^{+}+\mathrm{K}^{+}\right)$-ATPase catalytic unit, characterization of antiserum, and immunocytochemical localization in cerebellum, choroid plexus and kidney. J. Histochem. Cytochem. 32: 1309-1318.

Specht, S. C., and K. J. Sweadner (1984) Two different Na, K-ATPases in the optic nerve: cells of origin and axonal transport. Proc. Natl. Acad. Sci. U. S. A. 81 : 1234-1238.

Stahl, W. L., and D. G. Baskin (1984) Immunocytochemical localization of $\mathrm{Na}^{+}, \mathrm{K}^{+}$-adenosine triphosphatase in rat retina. J. Histochem. Cytochem. 32: $248-250$.

Stahl, W. L., and S. H. Broderson (1976) Localization of $\mathrm{Na}^{+}, \mathrm{K}^{+}$-ATPase in brain. Fed. Proc. 36: 1260-1265.

Sternberger, L. A. (1979) /mmunocytochemistry, Ed. 2, John Wiley \& Sons, Inc., New York.

Sweadner, K. J. (1979) Two molecular forms of $\left(\mathrm{Na}^{+}+\mathrm{K}^{+}\right)$-stimulated ATPase in brain. Separation, and difference in affinity for strophanthidin. J. Biol. Chem. 254: 6060-6067.

Ternynck, T., and S. Avrameas (1976) Polymerization and immobilization of proteins using ethylchloroformate and glutaraldehyde. Scand. J. Immunol. Suppl. 3: 29-35.

Thomas, R. C. (1972) Flectrogenic sodium pump in nerve and muscle cells. Physiol. Rev. 52: 563-594.

Towbin, H., T. Staehelin, and J. Gordon (1979) Electrophoretic transfer of proteins from polyacrylamide gels to nitrocellulose sheets: Procedure and some applications. Proc. Natl. Acad. Sci. U. S. A. 76: 4350-4354.

Trachtenberg, M. C., D. J. Packey, and T. Sweeney (1981) /n vivo functioning of the $\mathrm{Na}^{+}, \mathrm{K}^{+}$-activated ATPase. Curr. Top. Cell. Regul. 19: 159-217.

Ueno, S., H. Mayahara, I. Tsukahara, and K. Ogawa (1981). Ultracytochemical localization of ouabain-sensitive, potassium-dependent p-nitrophenylphosphatase activity in guinea pig retina. II. Neurons and Muller cells. Acta Histochem. Cytochem. 14: 186-206.

Urayama, O., and M. Nakao (1979) Organ specificity of rat sodium- and potassium-activated adenosine triphosphatase. J. Biochem. 86: 13711381.

Uyeda, C. T., L. F. Eng, and A. Bignami (1972) Immunological study of the glial fibrillary acidic protein. Brain Res. 37: 81-89.

Varon, S. S., and G. G. Somjen (1979) Neuro-Glia. Neurosci. Res. Program Bull. 17: 147-174.

Voller, A., D. E. Bidwell, and A. Bartlett (1979) The Enzyme Linked Immunosorbent Assay (ELISA). A Guide with Abstracts of Microplate Applications, A. Voller, D. E. Bidwell, and A. Bartlett, Publishers.

Vorbrodt, A. W. A. S. Lossinsky, and H. K. Wisniewski (1982) Cytochemical localization of ouabain-sensitive, $\mathrm{K}^{+}$-dependent $p$-nitrophenylphosphatase (transport ATPase) in the mouse central and peripheral nervous systems. Brain Res. 243: 225-234.

Walz, W., and L. Hertz (1982) Ouabain-sensitive and ouabain-resistant net uptake of potassium into astrocytes and neurons in primary cultures. $\mathrm{J}$. Neurochem. 39: 70-77.

Winslow, J. W. (1981) The reaction of sulfhydryl groups of sodium and potassium ion-activated adenosine triphosphatase with $N$-ethylmaleimide. The relationship between ligand-dependent alterations of nucleophilicity and enzymatic conformation states. J. Biol. Chem. 256: 9522-9531.

Wood, J. G., D. H. Jean, J. N. Whitaker, B.J. McLaughlin, and R.W. Albers (1977) Immunocytochemical localization of the sodium, potassium activated ATPase in knifefish brain. J. Neurocytol. 6: 571-581. 